\title{
Review
}

Amin Daei Sorkhabi, Aila Sarkesh, Alireza Daei Sorkhabi, Taher Entezari-Maleki, Jalil Rashedi and Hossein Bannazadeh Baghi*

\section{Vitamin supplementation as a potential adjunctive therapeutic approach for COVID-19: biological and clinical plausibility}

https://doi.org/10.1515/jbcpp-2021-0111

Received April 19, 2021; accepted July 17, 2021;

published online August 9, 2021

\begin{abstract}
The recent pandemic, severe acute respiratory syndrome coronavirus 2 (SARS-CoV-2), the causative agent of Coronavirus Disease 2019 (COVID-19) has introduced itself into the human population in the 21st century after the coronavirus diseases SARS-CoV and Middle East respiratory syndrome (MERS-CoV). Major investigations are underway worldwide in the search for pharmaceutical interventions for COVID-19 and many agents are administered in off-label routes. Several cases are under study to check or restrict clinical manifestations of COVID-19. According to the fact that the efficacy of some micro-nutrients like vitamins is proven to treat or prevent infectious diseases because of their antimicrobial and immunomodulatory activity, the
\end{abstract}

Amin Daei Sorkhabi and Aila Sarkesh are contributed equally to this work.

*Corresponding author: Hossein Bannazadeh Baghi, PhD, Immunology Research Centre, Tabriz University of Medical Sciences, Tabriz, Iran; Infectious and Tropical Diseases Research Center, Tabriz University of Medical Sciences, PO Box 5165665931, Tabriz, Iran; and Department of Virology, Faculty of Medicine, Tabriz University of Medical Sciences, Tabriz, Iran, E-mail: hbannazadeh@tbzmed.ac.ir, Phone: +98 4133364661 , Fax: +98 4133364661.

https://orcid.org/0000-0002-2513-5361

Amin Daei Sorkhabi and Aila Sarkesh, Student Research Committee, Tabriz University of Medical Sciences, Tabriz, Iran; Immunology Research Centre, Tabriz University of Medical Sciences, Tabriz, Iran; and Infectious and Tropical Diseases Research Center, Tabriz University of Medical Sciences, Tabriz, Iran

Alireza Daei Sorkhabi, Immunology Research Centre, Tabriz University of Medical Sciences, Tabriz, Iran; and Drug Applied Research Center, Tabriz University of Medical Sciences, Tabriz, Iran

Taher Entezari-Maleki, Department of Clinical Pharmacy, Faculty of Pharmacy, Tabriz University of Medical Sciences, Tabriz, Iran; and Cardiovascular Research Center, Tabriz University of Medical Sciences, Tabriz, Iran

Jalil Rashedi, Department of Laboratory Sciences, Faculty of Paramedicine, Tabriz University of Medical Sciences, Tabriz, Iran potential role of vitamins in the COVID-19 treatment or prevention must be considered.

Keywords: COVID-19; immunomodulatory functions; prophylaxis; treatment; vitamins.

\section{Introduction}

COVID-19 is associated with a wide spectrum of clinical manifestations ranging from asymptomatic to multi organ damage. This variability in clinical manifestations and severity of the disease is related to different factors including age, sex, nutritional status, habits, and comorbidities which can affect innate and adaptive immune response. Considering these factors can help to explore the most effective preventative and therapeutic options for COVID-19 [1, 2]. Although vaccination is the best option for countering the pandemic, since the time required immunizing 7.8 million people is lengthy, evidence-based effective treatment is urgent. Suboptimal immune responses to SARS-CoV-2 and severe complications in some population groups may be due to a variety of factors, the most prominent of which is micronutrient deficiency [3]. Malnutrition raises the risk of morbidity and mortality by increasing the rate of infections and extending recovery time since the immune system necessitates a variety of nutrients to function optimally. The general associations and extrapolations analysis signify the value of micronutrients and clinical practitioners are strongly advised to carry out a further search into treatment options [4]. Vitamins are the micronutrients with the most evidence for immune support and have been proposed to reduce the duration and severity of complications in viral infections because of their anti-inflammatory and antioxidant properties. These dietary supplements can attenuate vascular complications and overexpression of proinflammatory cytokines associated with infectious disease. Whether these agents could benefit COVID-19 patients is a research question worth investigating [5]. 
A wealth of clinical and preclinical observations suggested that insufficient vitamin levels were observed in hospitalized COVID-19 patients compared to the control group, which may explain the importance of vitamin supplementation in COVID-19 patients [6, 7]. Evidence supports the notion that, in addition to their specific and non-specific functions in immune system support, vitamins have a promising role in scavenging reactive oxygen species (ROS) and protecting cells from COVID-19induced oxidative damage [8]. They also participate in the modulation of the renin-angiotensin system (RAS), which in turn regulates the normal expression of the angiotensinconverting enzyme 2 (ACE2) receptor, a common binding site for SARS-CoV-2. Other COVID-19-induced complications, such as acute lung damage, endothelial dysfunction, and immune thrombosis, can be mitigated by these supplements $[9,10]$. Furthermore, evidence suggests that some vitamins, particularly vitamin $\mathrm{D}$, have antiviral effects and contribute to maintain respiratory homeostasis by either stimulating the exhibition of antimicrobial peptides or directly interfering with the replication of respiratory viruses. They may also exert activity in lung tissue and influence experimental interstitial pneumonitis. The objective of this review is to present the detailed therapeutic potential and physiological functions of vitamins in the management and treatment of COVID-19.

\section{Vitamin A}

Vitamin A is a multifunctional vitamin that is engaged in a wide range of biological processes. Retinol, retinal, and retinoic acid (RA) are the three main forms of vitamin A, with RA being the most physiologically active and all-trans retinoic acid (ATRA) being its main metabolite [11, 12]. Due to the different functions of vitamin A such as immunomodulatory and antimicrobial activity, it can be proposed as a beneficial approach to fight against viral infections such as COVID-19 [13]. Its immunomodulatory effects are perhaps the most pleiotropic, impacting not just development but also the functional fate of almost every cell involved in adaptive or innate immunity, whether protective or regulatory. This is especially important near the intestinal barrier, which' is where dietary vitamin $\mathrm{A}$ is absorbed [14]. Vitamin A keeps the immune system in check by regulating the activity of a number of innate and adaptive immune cells $[12,14]$. RA promotes the maturation of T helper 2 (Th2) cells and regulatory T cells (Tregs) while inhibiting Th1 and Th17 differentiation. It also stimulates $B$ cell differentiation and contributes to the maintenance of antibody production. Low levels of RA may result in an inadequate level of antibodies, notably immunoglobulin (Ig) A $[15,16]$. Retinoid induces monocyte differentiation toward macrophages and suppresses macrophage production of proinflammatory cytokines, contributing to the temporary transformation of M1 macrophages into M2 macrophages in the bone marrow, resulting in immunomodulation [12]. Individuals with vitamin A deficiency encounter problems with lymphocyte development and function that are linked to $\mathrm{C}-\mathrm{C}$ motif chemokine receptor 9 (CCR9) and 4-7-integrin. Vitamin A deficiency limits the number of $\mathrm{T}$ and $\mathrm{B}$ cells in the lamina propria of the small intestine, rendering it susceptible to pathogens received through the diet [9]. RA is linked to the balance of Th1 and Th2 cells, implying that in individuals with vitamin A deficiency, Th2 differentiation, and Th1-Th2 balance are disrupted [17, 18]. Vitamin A has been demonstrated in several studies to be able to regulate the production of interleukin-10 (IL-10) by Th2 cells. It inhibits the synthesis of proinflammatory Th1-type cytokines including interferon (IFN) and IL-2 in both T and natural killer (NK) cells, making it anti inflammatory [19]. Thus, this process is linked to the lack of some infections to elicit inflammatory responses [20, 21].

Coronaviruses can suppress type-I interferon (IFNI)mediated antiviral responses, limiting therapeutic approaches [22]. According to recent research by di Bari et al., SARS-CoV-2 may exploit a host TF implicated in IFN, RA signaling, and ribonucleic acid (RNA) polymerase II transcription regulation to facilitate its replication cycle. Through this mechanism, it may be able to compete to steal the human TF that is engaged in these processes. It has prompted scientists to compile a compelling body of data indicating that SARS-CoV-2 can impair IFN-I signaling in host cells as well as explaining the mechanism of SARS retinoic acid depletion syndrome, which culminates in a cytokine storm [23]. Since the host's IFNI response to SARS-CoV-2 is linked to retinol storage and endogenous RA serum concentrations, sufficient amounts of vitamin A can contribute to enhanced outcomes [24]. Since retinoids can potentiate the function of IFN-I consumption of retinoids in combination with IFN-I against COVID-19 may have beneficial effects. Thus, vitamin A supplementation in COVID-19 patients may yield encouraging outcomes, suggesting it as an adjunctive treatment for COVID-19; nevertheless, further research is required. Regarding evidence, COVID-19 patients have a substantial decrease in RA storage which can be also manifested as conjunctivitis or pink eye [24, 25]. Three mechanisms are underlying low RA levels in these patients, which are as follows: First, the change of lipofibroblasts to active myofibroblasts, which deposit extracellular matrix proteins abundantly and lose their retinoid reserves, is a 
hallmark of SARS-CoV-2-induced pulmonary fibrosis. Second, since lipofibroblasts rely on retinoids to initiate, coordinate, and regulate alveolar septal eruption and alveologenesis, inflammation-induced reductions in RA uptake and metabolism to polar metabolites may impair the lung's capacity to regenerate from pulmonary fibrosis. Third, the capacity to transport retinoid to the lung is impaired during severe infection due to a decline in circulating vitamin A levels [26]. Retinoid signaling may be the main pathogenetic disorder in COVID-19 which can be used to influence the development of adjuvants, therapeutic targets, and potential medicines [24, 27]. Likewise, a recent retrospective cohort study of individuals with post infectious olfactory impairment, a long-term consequence in COVID-19 patients, discovered that topically administering vitamin A at a dose of 10,000 IU/day for eight weeks improved clinical outcome [28, 29].

In COVID-19, the development of acute respiratory distress syndrome (ARDS) is primarily linked to inflammatory cytokine release and the subsequent exudative liquid buildup. The impact of retinol derivatives lecithin, colin, and inositol deficiency in the medium on ARDS pathogenesis and the probable reduction of surfactant synthesis due to RA deficiency in the body owing to a severe catabolic state and severe infection should not be neglected. These retinol compounds play a significant role in surfactant structure and are essential issues that must be researched concerning the development and severity of the ARDS presentation [30]. In this way, Yang et al. discovered that RA-SS therapy significantly decreased inflammatory infiltration and proliferative alterations in the pulmonary stroma [31].

The evidence suggests that the impact of vitamin A is dose-dependent [32]. Accordingly, low-dose RA stimulates the release of inflammatory mediators at physiological doses $(1 \mathrm{nM})$. According to a case-control study, the length of symptom and mean SPO2 variations in patients receiving vitamin A after 24 and $48 \mathrm{~h}$ revealed a marginally nonsignificant improvement over placebo. To avoid a respiratory viral infection, the recommended dose for elderly individuals, adults, and adolescents is to supplement 2,000-4,000 IU vitamin A per day, and the optimal vitamin A dose as supportive therapy after hospitalization for severe COVID-19 is as follows: Based on current evidence, all COVID-19 patients should receive an initial bolus dosage of vitamin A ranging from 50,000 to 200,000 IUs. Following that, 10,000 IU vitamin A should be administered for a month, continued by 5,000 IU orally [33].

Furthermore, research suggests that calves given dietary vitamin A $(3,300 \mathrm{U} / \mathrm{kg}$ dry matter diet) exhibited higher serum retinol levels and a stronger IgG1 response to bovine coronavirus intramuscular inoculations. Surprisingly, these immunized vitamin A supplemented calves had a greater IgG1 to IgG2 ratio. Immune response to mucosal bovine respiratory syncytial virus (BRSV) vaccine was impaired in vitamin A deficient individuals owing to this adjuvant-like ability; hence vitamin A may be worth considering for coadministration alongside vaccine trials in the future [33].

\section{B vitamins}

B vitamins are a vitamin family with at least eight members that contribute to cell metabolic pathways while also having a remarkable association with immune responses [34]. Studies on the correlation of B vitamins with immune responses and prevailing viral infections, such as SARS-CoV-2 infection, suggest that B vitamins play a key role in innate and adaptive immune responses. The involvement of vitamins B6 and B9 in nucleic acid and amino acid synthesis supports an undeniable link between $B$ vitamins and immune responses [35]. B vitamins have been shown to modulate proinflammatory immune responses as well as their significant association with alleviating multi organ clinical manifestations in COVID-19 patients by affecting cytokines levels, enhancing pulmonary function, and endothelial integrity, in addition to its specific role in preventing coagulopathies [36]. The significance of vitamin B in the prognosis and treatment of COVID-19 patients has compelled clinicians to consider vitamin $B$ as a nonpharmaceutical adjunct to current treatments and to assess vitamin B status in COVID-19 patients, which has been suggested to have an inverse correlation with the length of hospitalization in these patients [37]. Furthermore, studies suggest that vitamin $B$ has a complicated dominance in controlling immune responses via mucosa-associated invariant T (MAIT) cells, which are primarily found in the intestine, liver, and lung and express a semi invariant $\mathrm{T}$ cell receptor restricted by the major histocompatibility complex (MHC) class 1-related molecule [38, 39].

\section{Vitamin B1}

Vitamin B1 (thiamine) has been linked to the adequacy of humoral immune responses in COVID-19 patients, with a lack of B1 resulting in an abnormal antibody response, which can lead to serious consequences such as neuroinflammation and cardiovascular complications [36]. 
Thiamine has a significant anti inflammatory effect and can diminish cytokine storms in individuals who have a proinflammatory reaction [40]. Thiamine deficiency has been believed to trigger a proinflammatory response in Th1 and Th17 cells, since these cells play an important role in the management of COVID-19, appropriate amounts of this vitamin should be considered in COVID-19 cases [40]. In COVID-19 patients with severe symptoms, daily $500 \mathrm{mg}$ thiamine is recommended [41, 42]. Furthermore, vitamin B1 deficiency has been shown to alter the tricarboxylic acid cycle, resulting in fewer naive B cells in Peyer's patches; as a result, individuals with vitamin B1 deficiency are more susceptible to infections obtained from the diet [38]. Encephalopathy is a neurological complication of COVID-19, and according to a case series research, thiamine replacement may be beneficial for COVID-19-associated encephalopathy by improving functional outcomes and lowering mortality [41]. According to the findings of Al Sulaiman et al., administering thiamine to COVID-19 patients admitted to the intensive care unit (ICU) reduced the risk of thrombosis by $81 \%$ as compared to the control group showing the potential of thiamine in enhancing the prognosis of COVID-19 patients [43].

\section{Vitamin B2}

Vitamin B2 (riboflavin) has been shown to be capable of altering the nucleic acids of microbial pathogens in the presence of ultraviolet (UV) radiation, causing detrimental effects on these microorganisms and inhibiting their replication in in vitro experiments [35]. Although the risk of SARS-CoV-2 infection by transfusion is believed to be minimal, utilizing a PI technology such as riboflavin and UV light may be a vital first line of defense against a threat [44]. The use of convalescent plasma (CP) is a suggested therapeutic method for COVID-19 in which riboflavin plays a key role [44]. CP is a therapy in which putatively antibody-rich plasma is extracted and transfused from patients who have recovered from the disease to provide passive immunity to the disease [35]. It is the most widely available source of anti-SARS-CoV-2 antibodies, and its use is universally accepted. Pathogen reduction utilizing riboflavin and UV light dramatically lower SARS-CoV-2 infectivity in inoculated plasma and whole blood. Previous research on the relationship between vitamin B2 and MERS-CoV infection revealed the positive efficacy of vitamin $\mathrm{B} 2$ in patients with MERS-CoV infection, proposing a powerful beneficial contribution of vitamin B2 to SARS-CoV-2 infection [35].

\section{Vitamin B3}

Vitamin B3 (niacin) contributes to producing nicotinamide adenine dinucleotide $\left(\mathrm{NAD}^{+}\right)$and nicotinamide adenine dinucleotide phosphate (NADP), which play an initial role in chronic systemic inflammation by functioning as a coenzyme in various metabolic pathways that must be regulated to overcome various pathophysiological conditions [36]. Almost all processes in the COVID-19 molecular disease pathway are either triggered by or arose from $\mathrm{NAD}^{+}$ depletion [45]. It is mediated by NAD and adenosine triphosphate (ATP), and excessive NAD intake lowers ATP levels, resulting in cognitive impairment. Besides that, despite RAS activation, COVID-19 patients' aldosterone levels drop and they become hypovolemic. It appears that aldosterone synthesis is turned off somewhere in the CNS or the adrenal gland [46]. The inevitable fact serotonin deficiency is a key molecule that serves a number of activities, including stimulating aldosterone release. The tryptophan resources, which serve as the raw material for the production of serotonin and $\mathrm{NAD}$, are depleted in COVID-19 patients [47]. Also, concerning ARDS, serotonin levels drop, resulting in hypoaldosteronism. Hyponatremia and hypovolemia are two conditions that can occur. Fatigue and varying degrees of mood problems are the most common symptoms. NAD, ATP, and serotonin decline all have effects that may be handled by NAD, niacin, and other supplements taken concurrently [48].

$\mathrm{NAD}^{+}$, which is increased by vitamin $\mathrm{B} 3$ revealed to be associated with immunomodulation by inhibiting the release of proinflammatory cytokines like IL-1 $\beta$, IL-6, and tumor necrosis factor $\alpha$ (TNF- $\alpha$ ) [49]. Moreover, studies have demonstrated that vitamin B3 contributes to managing cytokine release status in COVID-19 patients by affecting IL-6 [27]. It is also capable of exerting anti inflammatory and immunomodulatory effects through hindering neutrophil infiltration, especially in patients with ventilator-induced lung injury [50]. Recent investigations have shown that niacin may efficiently bind to certain proteins in the novel coronavirus; it is hypothesized that niacin may be able to bring the IL-1B to target the SARS-CoV-2 as a result of these bindings. Overall, it is anticipated that niacin adjuvant supplementation may improve the therapeutic effectiveness of current clinical 
antiviral medications and immunotherapy in the treatment of the fatal COVID-19 [40].

\section{Vitamin B6}

Vitamin B6 (pyridoxine) is required as a coenzyme in many inflammatory pathways, antibody, cytokine, sphingosine, and tryptophan metabolism, as in the regulation of endothelial integrity, platelet aggregation, maintaining cytotoxic activity of NK cells, B-cell antibody production, the clotting cascade, and blood pressure regulation via reninangiotensin secretion [51]. Its deficiency impairs lymphocyte prefiltration and IL-2 production in response to mitogens and immunization-induced antibody synthesis. Pyridoxal phosphate (PLP), also known as an active form of vitamin $\mathrm{B} 6$ has been shown to play a role in alleviating COVID-19 manifestation by regulating proinflammatory cytokines, while also affecting endothelial integrity and avoiding coagulopathies [52,53]. The precise mechanism of PLP's immune-modulatory function has not been elucidated; however, it is conceivable that the interaction of proxy radicals with PLP scavenges free radicals owing to the pyridine's amino group [54, 55]. Vitamin B6 has been identified to have an essential role in the maintenance and function of lymphoid tissues. Immune deficiencies such as lymphoid atrophy, lymphopenia, and disturbed primary and secondary antibody response develop in individuals with vitamin B6 deficiency [39].

The administration of an adequate dose of vitamin B6 to COVID-19 patients has been proposed as an adjunctive treatment, even via supplementing formulas, to better stabilize the disruption of cellular metabolism of the homocysteine pathway induced by the SARS-CoV-2 infection [56]. Vitamin B6 defined requirements are $1.6 \mathrm{mg} /$ day for females and $1.7 \mathrm{mg} /$ day for males, with a UL of $25 \mathrm{mg} /$ day for both. In the case of being pregnant or lactating (1.8 and $1.7 \mathrm{mg} /$ day, respectively), requirement values are raised, while PRI and UL are decreased for children and infants [57].

Vitamin B6 is thought to regulate hyperinflammation by blocking the NLRP3 inflammasome, therefore decreasing viral spread and cytokine storm, at least in part. Its anti inflammasome action implies that it may have a therapeutic effect in reducing the severity of COVID-19 and its implications, which is in accordance with the notion that the NLRP3 inflammasome plays a key role in chronic diseases including CVD, diabetes, and acute viral pneumonia [58]. Altogether, it may be effective in preventing the severity of COVID-19 and its complications [59].

\section{Vitamin B9}

Vitamin B9 (folate) is a vital component of DNA synthesis, and its deficiency reduces the formation of proteins, nucleic acids, and immune cells. It plays a crucial role in the adaptive immune response by inhibiting furin, an enzyme involved in bacterial and viral infections that have been identified as a promising therapeutic target [60]. It disrupts SARS-CoV-2 binding and cell entry by blocking furin, which is an early phase in the virus's pathogenesis. Thus, vitamin B9 contributes to the management of COVID-19 in the early stages of the disease [60]. Moreover, Tregs must be differentiated from naive T cells, which necessitates the need for vitamin $\mathrm{B} 9$ [61]. The function of $\mathrm{CD}^{+}$ $\mathrm{T}$ cells and NK cells are disrupted in individuals with vitamin B9 deficiency, resulting in significant unfavorable outcomes in prevailing a variety of infections [39].

Another potential benefit of supplementing vitamin B9 is its advantageous impact on minimizing oxidative damage following COVID-19 via increasing the activity of antioxidant enzymes. The SARS-CoV-2 infection causes one of the most striking alterations in intracellular metabolomics, resulting in depleted levels of intracellular glucose and folate, supporting the hypothesis that host glucose and folate metabolism were hijacked to fulfill the demand for viral subgenomic RNA replication [62]. Simultaneously, there is a significant drop in host mRNA abundance, which is presumed to have been destabilized by SARS-CoV-2's host "shut-off" activity to salvage host nucleotide supply for viral biosynthesis [62]. Furthermore, evidence highlighted that 5-10 mg per day orally (or 50-100 mcg intravenously of the active form 5-methyltetrahydrofolate may have a favorable impact on pulmonary perfusion or the treatment of pulmonary hypertension, both directly and indirectly, by improving the efficacy of inhaled nitric oxide (iNO) or avoiding tachyphylaxis to iNO, at least in some individuals, with minimal risk of adverse effects [63, 64]. Levomefolic acid has the capacity to inhibit SARS-CoV-2 Spike protein from binding to the human ACE2 receptor. As a result, this medication should be considered for further in vitro studies as an ACE2 and spike protein inhibitor candidate [65].

\section{Vitamin B12}

Vitamin B12 (cobalamin) contributes to the healthy balance of the immune system. So inadequate levels of this vitamin can significantly alter immune responses by affecting the production of nucleic acid, protein synthesis, inhibiting 
the activity of immune cells, and interfering with metabolic processes, including methylation and serine, glycine, and purine cycles [66].

SARS-CoV-2 could interfere with vitamin B12 metabolism, culminating in vitamin B12 depletion, which may manifest as increased oxidative stress and lactate dehydrogenase, hyperhomocysteinemia, activation of the coagulation cascade, vasoconstriction, and renal and pulmonary vasculopathy [36]. Vitamin B12 deficiency can also cause respiratory, gastrointestinal, and neurological complications in COVID-19 patients [67, 68]. Oxidative stress and homocysteine levels rise in COVID-19 patients, along with an elevated lactate dehydrogenase (LDH) level, thrombocytopenia, low reticulocyte count, intravascular coagulation thrombosis, and renal and pulmonary vasculopathy, all of which occur in both B12 deficiency and COVID-19, resulting in respiratory, gastrointestinal, and central nervous system (CNS) impairments [34].

Low levels of B12 in critically ill patients lead to an increase in methylmalonic acid and homocysteine, which causes inflammation and intensifies disease severity, implying a link between vitamin B12 deficiency and the development of inflammation [69]. According to the fact that cobalamin acts as an antioxidant and an anti inflammatory agent, it can protect against multiple organ dysfunction by modulating the activity of certain cytokines, growth factors, and other substrates. As a result, high-dose intravenous or intramuscular injections could be used as part of a novel strategy to treat COVID-19 patients with ARDS. To consider vitamin B12 as a pharmaconutrient, however, higher doses than those currently recommended for routine parental nutrition (PN) or enteral nutrition (EN) therapy will be required [70]. Furthermore, vitamin B12 role in enhancing cellular immunity through an interaction with $\mathrm{CD}^{+}$and NK cells suggests the efficacious role of vitamin B12 in COVID-19 prevention, prognosis, and treatment [71]. Since folate affects various conditions in which pulmonary hypertension occurs, it is hypothesized that it may have a specific benefit for patients with hypoxemia associated with severe pneumonia in which iNO therapy is conducted. In a study by Esko Wiltshire et al., it was hypothesized that daily oral administration of 5-10 mg folic acid or the equivalent intravenous dose of $50-100 \mathrm{mcg}$ of the active form 5-methyltetrahydrofolate might rapidly improve hypoxemia due to pulmonary hypertension and prevent tachyphylaxis to iNO therapy [64].

Anemia is a common and persistent finding in COVID-19 patients during hospitalization, and vitamin B12 supplementation is appropriate. The British National Formulary currently recommends $1,000 \mu \mathrm{g}$ of $\mathrm{OH}-\mathrm{B} 12$ intramuscularly three times per week for two weeks, then once every three months for pernicious anemia and other macrocytic anemias in the individuals without neurological dysfunction [72]. A clinical trial found that giving COVID-19 patients with $500 \mathrm{mg}$ of vitamin B12 along with 1,000 IU vitamin D and magnesium reduces the severity of symptoms as well as the need for oxygen and intensive care support [73]. Overall, cobalamin has been shown to be efficacious in alleviating COVID-19 manifestations [74, 75].

\section{Vitamin C}

Vitamin C is widely acknowledged as a helpful therapeutic agent for respiratory infections owing to its antioxidative, anti inflammatory, and immune-supportive properties [76]. Vitamin C is a water-soluble vitamin that reduces numerous free radicals and oxidants by one or two electrons. According to the research, vitamin $\mathrm{C}$ has antiviral properties; a study performed by Nina A. Mikirova et al. established that vitamin $\mathrm{C}$ can diminish Epstein-Barr virus (EBV) early antigen activity and viral load [77]. Furthermore, studies have shown that administering vitamin $\mathrm{C}$ in combination with antiviral medicines like ganciclovir and foscarnet for pretreatment of human foreskin fibroblast and endothelial cells infected with cytomegalovirus (CMV) leads to lower viral load and replication; meanwhile, the administration of antiviral drugs in the absence of vitamin $\mathrm{C}$ had no noticeable impact on viral replication. Also, vitamin $C$ has been shown to suppress viral replication in individuals infected with herpes simplex virus-1 (HSV-1), influenza type A virus, poliovirus type 1 , and rhinovirus [78]. Vitamin $\mathrm{C}$ is essential for immune defense as it regulates multiple cellular processes in both the innate and adaptive immune systems. It has been shown to contribute to the differentiation and maturation of $\mathrm{T}$ and $\mathrm{NK}$ cells, as well as their resistance to certain cell death stimuli, resulting in improved cellular immune responses and antibody production [79]. Also, it has been found to interact with pathogen-induced lipopolysaccharide (LPS), which is associated with the production of proinflammatory cytokines such as TNF- $\alpha$ and IFN- $\gamma$, while also increasing anti inflammatory IL-10, which serves as an immunomodulatory agent [79]. Lymphocytes and neutrophils receive support from vitamin C's antioxidant protection. Neutrophils accumulate large amounts of vitamin C via the sodium-dependent vitamin $\mathrm{C}$ transporter 2 (SVCT2), and they may also accumulate vitamin $\mathrm{C}$ in the oxidized form, dehydroascorbate (DHA), via glucose transporters (GLUTs) [79]. It typically occurs after the oxidative burst is triggered; showing that vitamin $\mathrm{C}$ protects these cells from oxidative damage. Furthermore, investigations have 
shown that vitamin $\mathrm{C}$ has the capacity to inhibit the formation of extracellular neutrophil traps, which are linked to death and multi organ damage in COVID-19 patients $[80,81]$. It restricts monocytes via altering intracytoplasmic cytokine synthesis, resulting in decreased release of pro inflammatory cytokines such as IL-1, IL-2, IL-6, and TNF- $\alpha$, as well as its propensity to inhibit nuclear factor-B (NF-B). This characteristic of vitamin $C$ protects against cytokineinduced damage associated with a number of infectious diseases [79]. It also stimulates lymphocyte proliferation, which optimizes antibody response, in addition to its efficiency in reinforcing the oxidant-sensitive caspasedependent apoptotic pathway that occurs following neutrophil immune responses against pathogens. It plays an early role in apoptosis and the clearance of neutrophils from inflammatory sites via macrophages, therefore protecting the body from severe tissue damage [82, 83]. It is supported by research on peritoneal isolated neutrophils from Gulo mice with vitamin C deficiency, which illustrates that apoptosis impairment of neutrophils ensued by vitamin C deficiency leads to long stability of these immune cells in sites of inflammation and the occurrence of necrotic cell death in neutrophils [80].

Even though the vitamin $C$ levels of patients with COVID-19 have not ever been stated in the literature, it is speculated that the vitamin $\mathrm{C}$ status of patients with community-acquired pneumonia is evacuated and is linked to increased oxidative stress. However, it is not well understood whether vitamin C deficiency is a cause or a consequence of severe infection since requirements for vitamin C increase [84]. Previous research has shown that vitamin $\mathrm{C}$ status in individuals with respiratory infections, particularly those with severe vitamin $\mathrm{C}$ deficiency, has a striking association with the severity of outcomes [85].

Vitamin C supplementation has been proven effective for prophylaxis and treatment of the COVID-19 due to its various impacts on immune responses and other specific implications [86, 87] (Table 1). The infection raises oxidant levels and activates the nuclear factor kappa-B (NF-kB) pathway. NF- $\mathrm{kB}$ initiates a signaling cascade that culminates in an increase in reactive oxygen species (ROS) and other inflammatory mediators which ultimately leads to inflammation [38]. Previous SARS-CoV pandemic experience suggests that vitamin $C$ plays an important role in prevailing free oxidative radicals and viral infections, proposing it as a generic therapy for severe viral respiratory infections [102]. Upon SARS-CoV-2 infection, the first line of innate immunity is displayed by neutrophil recruitment into infected tissues and the response against host-derived inflammatory signals (tissue damage signals) and pathogens. The migration of large numbers of neutrophils to the infection site is ensued by the expression of more than 30 chemokines $[8,42,103]$.

Several studies have been conducted to explore vitamin C's potent anti inflammatory properties. This vitamin has been demonstrated to suppress the NF- $\mathrm{kB}$ pathway as well as hinder cytokine production in septic Gulo knockout mice [103]. Moreover, animal studies have shown that leukocytes derived from vitamin C-treated pigs as compared to a control group, full chemotactic functions enhanced neutrophil phagocytosis, which corresponds to infection cure [104]. In this way, Johnston et al. discovered that vitamin $C$ had an antihistamine impact with increased chemotaxis, which is another attribute in the battle against inflammation [105]. Vitamin C has been shown to reduce IFN $\gamma$, proinflammatory cytokines TNF- $\alpha$ and IL- 6 production, while enhancing anti inflammatory IL-10 production which are crucial in battling against COVID-19. As a result of its anti inflammatory characteristics, vitamin $\mathrm{C}$ may have a role to play in reducing the pathogenesis induced by SARS-CoV-2 infection, hence enhancing the patient's recovery $[106,107]$. Indeed, in a preliminary pilot study of COVID-19 patients requiring intensive care, high-dose intravenous vitamin C significantly improved oxygenation, diminished organ-damaging cytokine storm (IL-6), and showed a tendency toward lower mortality in critically ill patients [108, 109]. Another pilot study discovered inadequate vitamin C and vitamin D serum levels in the majority of critically ill COVID-19 patients. Older age and a deficit in vitamin $\mathrm{C}$ were revealed to be codependent risk factors for mortality [110].

Clinical trials have shown that administering highdose intravenous vitamin C ( $24 \mathrm{~g} /$ day) for seven days to individuals with severe COVID-19 leads to considerable positive outcomes [111]. Additionally, clinical trials on severely ill COVID-19 patients show that extra bolus doses of vitamin $C$ result in a promising outcome. Even a 50,000 mg vitamin C infusion over $4 \mathrm{~h}$ in severely ill patients led to major remission with no complaints of adverse side effects [98].

Though the pilot trial found that adding high-dose (24 g per day for seven days) intravenous vitamin $\mathrm{C}$ to the standard-of-care treatment for severe COVID-19 seemed not to affect ventilation-free days, it might indicate a possible benefit in oxygenation and IL- 6 release [100]. High levels of IL- 6 were found in COVID-19 patients, indicating that it might be used as a biomarker for disease severity. COVID-19 induces a wide range of biological consequences, including pulmonary infiltration and organ damage [112]. Furthermore, a recent meta-analysis based on data from eight vitamin $C$ trials involving a total of 685 patients found that vitamin $\mathrm{C}$ shortened the time spent on mechanical ventilation in critically ill patients [113]. Zhang 
Table 1: The table summarizes recent clinical trials concerning the administration of various micronutrients to COVID-19 patients of various clinical classifications.

\begin{tabular}{|c|c|c|c|c|c|c|}
\hline Study & esign & Sample size & Clinical classification & Intervention & Comparator & Outcomes \\
\hline $\begin{array}{l}\text { Abulmeaty } \\
\text { et al. [3] }\end{array}$ & $\begin{array}{l}\text { Placebo- } \\
\text { controlled, } \\
\text { double-blind } \\
\text { randomized trial }\end{array}$ & $\begin{array}{l}\text { Intervention: } \\
18 \\
\text { Comparator: } \\
16\end{array}$ & $\begin{array}{l}\text { Non-critical COVID-19 } \\
\text { patients }\end{array}$ & $\begin{array}{l}1,500 \text { ug vitamin } A \text {, } \\
250 \mathrm{mg} \text { vitamin } C, \\
90 \mathrm{mg} \text { vitamin } \mathrm{E}, 15 \mu \mathrm{g} \\
\text { selenium, and } 7.5 \mathrm{mg} \\
\text { zinc }\end{array}$ & Placebo & $\begin{array}{l}\text { The lower cytokine storm } \\
\text { and improved clinical } \\
\text { parameters in the inter- } \\
\text { vention group compared } \\
\text { to the comparator group }\end{array}$ \\
\hline $\begin{array}{l}\text { Icala-Diaz } \\
\text { al. [88] }\end{array}$ & $\begin{array}{l}\text { Retrospective, } \\
\text { observational, } \\
\text { cohort study }\end{array}$ & $\begin{array}{l}\text { Intervention: } \\
79 \\
\text { Comparator: } \\
458\end{array}$ & Not reported & $\begin{array}{l}0.532 \mathrm{mg} \text { oral calcife- } \\
\text { diol and } 0.266 \mathrm{mg} \text { on } \\
\text { days } 3 \text { and } 7 \text { then } \\
\text { weekly until discharge } \\
\text { or ICU admission }\end{array}$ & $\begin{array}{l}\text { No adjunctive } \\
\text { intervention }\end{array}$ & $\begin{array}{l}\text { The lower mortality rate in } \\
\text { the intervention group } \\
\text { (5\%) compared to the } \\
\text { comparator group ( } 20 \%)\end{array}$ \\
\hline $\begin{array}{l}\text { nnweiler } \\
\text { al. [89] }\end{array}$ & $\begin{array}{l}\text { Quasi } \\
\text { experimental }\end{array}$ & $\begin{array}{l}\text { Intervention: } \\
57 \\
\text { Comparator: } \\
9\end{array}$ & Not reported & $\begin{array}{l}80,000 \text { IU oral chole- } \\
\text { calciferol either within } \\
\text { a week following the } \\
\text { suspicion, diagnosis or } \\
\text { during the prior month }\end{array}$ & $\begin{array}{l}\text { No adjunctive } \\
\text { intervention }\end{array}$ & $\begin{array}{l}\text { The lower mortality rate in } \\
\text { the intervention group } \\
(17.5 \%) \text { compared to the } \\
\text { comparator group } \\
(55.6 \%)\end{array}$ \\
\hline $\begin{array}{l}\text { nnweiler } \\
\text { al. [90] }\end{array}$ & $\begin{array}{l}\text { Quasi } \\
\text { experimental }\end{array}$ & $\begin{array}{l}\text { Intervention: } \\
16 \\
\text { Comparator: } \\
32\end{array}$ & Not reported & $\begin{array}{l}80,000 \text { IU oral chole- } \\
\text { calciferol within a few } \\
\text { hours of diagnosis }\end{array}$ & $\begin{array}{l}\text { No adjunctive } \\
\text { intervention }\end{array}$ & $\begin{array}{l}\text { The lower } 14 \text {-day mortal- } \\
\text { ity rate in the intervention } \\
\text { group }(18.8 \%) \text { compared } \\
\text { to the comparator group } \\
(31.3 \%)\end{array}$ \\
\hline $\begin{array}{l}\text { Castillo et al. } \\
\text { [86] }\end{array}$ & $\begin{array}{l}\text { Open-label, ran- } \\
\text { domized, and } \\
\text { controlled trial }\end{array}$ & $\begin{array}{l}\text { Intervention: } \\
50 \\
\text { Comparator: } \\
26\end{array}$ & Not reported & $\begin{array}{l}0.532 \mathrm{mg} \text { oral calcife- } \\
\text { diol and } 0.266 \mathrm{mg} \text { on } \\
\text { days } 3 \text { and } 7 \text { then } \\
\text { weekly until discharge } \\
\text { or ICU admission }\end{array}$ & $\begin{array}{l}\text { No adjunctive } \\
\text { intervention }\end{array}$ & $\begin{array}{l}\text { The lower need for ICU } \\
\text { admission the interven- } \\
\text { tion group ( } 2 \% \text { ) compared } \\
\text { to the comparator group } \\
(50 \%)\end{array}$ \\
\hline $\begin{array}{l}\text { Gao et al. } \\
{[91]}\end{array}$ & $\begin{array}{l}\text { Retrospective, } \\
\text { observational, } \\
\text { and cohort study }\end{array}$ & $\begin{array}{l}\text { Intervention: } \\
46 \\
\text { Comparator: } \\
30\end{array}$ & $\begin{array}{l}\text { Moderate to critically } \\
\text { ill COVID-19 patients }\end{array}$ & $\begin{array}{l}6 \mathrm{~g} \text { intravenous vitamin } \\
\mathrm{C} \text { per } 12 \mathrm{~h} \text { on the first } \\
\text { day, and } 6 \mathrm{~g} \text { once for } \\
\text { the following four days }\end{array}$ & Standard care & $\begin{array}{l}\text { The lower mortality in the } \\
\text { intervention group }(2.2 \%) \\
\text { compared to the compar- } \\
\text { ator group ( } 16.7 \%)\end{array}$ \\
\hline $\begin{array}{l}\text { Giannini } \\
\text { et al. [92] }\end{array}$ & $\begin{array}{l}\text { Retrospective, } \\
\text { observational, } \\
\text { and cohort study }\end{array}$ & $\begin{array}{l}\text { Intervention: } \\
36 \\
\text { Comparator: } \\
55\end{array}$ & $\begin{array}{l}\text { Comorbid COVID-19 } \\
\text { patients }\end{array}$ & $\begin{array}{l}400,000 \text { IU oral chole- } \\
\text { calciferol ( } 200,000 \text { IU } \\
\text { administered in two } \\
\text { consecutive days) }\end{array}$ & $\begin{array}{l}\text { No adjunctive } \\
\text { intervention }\end{array}$ & $\begin{array}{l}\text { The lower need for ICU } \\
\text { support or mortality rate } \\
\text { in the intervention group } \\
\text { (38.9\%) compared to the } \\
\text { comparator group } \\
(52.7 \%)\end{array}$ \\
\hline $\begin{array}{l}\text { Hakamifard } \\
\text { et al. [93] }\end{array}$ & $\begin{array}{l}\text { Open-label, ran- } \\
\text { domized, and } \\
\text { controlled trial }\end{array}$ & $\begin{array}{l}\text { Intervention: } \\
38 \\
\text { Comparator: } \\
34\end{array}$ & Not reported & $\begin{array}{l}1,000 \mathrm{mg} \text { daily oral } \\
\text { vitamin C and } 400 \mathrm{IU} \\
\text { daily vitamin } \mathrm{E}\end{array}$ & $\begin{array}{l}\text { No adjunctive } \\
\text { intervention }\end{array}$ & $\begin{array}{l}\text { The outcomes didn't } \\
\text { differ in the intervention } \\
\text { group compared to the } \\
\text { comparator group }\end{array}$ \\
\hline $\begin{array}{l}\text { Hiedra et al. } \\
\text { [94] }\end{array}$ & $\begin{array}{l}\text { Retrospective, } \\
\text { observational, } \\
\text { Case series study }\end{array}$ & $\begin{array}{l}\text { Intervention: } \\
17\end{array}$ & $\begin{array}{l}\text { Moderate to severe } \\
\text { COVID-19 patients }\end{array}$ & $\begin{array}{l}1 \mathrm{~g} \text { intravenous vitamin } \\
\mathrm{C} \text { every } 8 \mathrm{~h} \text { for three } \\
\text { days }\end{array}$ & Not applicable & $\begin{array}{l}\text { The significant decrease } \\
\text { in inflammatory markers } \\
\text { and lower FiO2 } \\
\text { requirements in the } \\
\text { intervention group }\end{array}$ \\
\hline $\begin{array}{l}\text { Lakkireddy } \\
\text { et al. [95] }\end{array}$ & $\begin{array}{l}\text { Open-label, ran- } \\
\text { domized, and } \\
\text { controlled trial }\end{array}$ & $\begin{array}{l}\text { Intervention: } \\
65 \\
\text { Comparator: } \\
65\end{array}$ & $\begin{array}{l}\text { Mild to moderate } \\
\text { COVID-19 patients } \\
\text { with hypovitaminosis } \\
\text { D }\end{array}$ & $\begin{array}{l}60,000 \text { IU vitamin } D \text { per } \\
\text { day for eight days for } \\
\text { subjects with } \\
18 \leq \mathrm{BMI} \leq 25 \text { and } \\
10 \text { days for subjects } \\
\text { with } \mathrm{BMI}>25\end{array}$ & $\begin{array}{l}\text { No adjunctive } \\
\text { intervention }\end{array}$ & $\begin{array}{l}\text { Improvement in vitamin D } \\
\text { level to } 80-100 \mathrm{ng} / \mathrm{mL} \\
\text { significantly mitigated } \\
\text { inflammatory markers } \\
\text { associated with COVID-19 } \\
\text { with no adverse effects. }\end{array}$ \\
\hline
\end{tabular}


Table 1: (continued)

\begin{tabular}{|c|c|c|c|c|c|c|}
\hline Study & Design & Sample size & Clinical classification & Intervention & Comparator & Outcomes \\
\hline $\begin{array}{l}\text { Murai et al. } \\
{[96]}\end{array}$ & $\begin{array}{l}\text { Placebo- } \\
\text { controlled, } \\
\text { double-blind } \\
\text { randomized trial }\end{array}$ & $\begin{array}{l}\text { Intervention: } \\
120 \\
\text { Comparator: } \\
120\end{array}$ & $\begin{array}{l}\text { Moderate to severe } \\
\text { COVID-19 patients }\end{array}$ & $\begin{array}{l}\text { Single dose of } \\
200,000 \text { IU oral } \\
\text { cholecalciferol }\end{array}$ & Placebo & $\begin{array}{l}\text { The hospitalization } \\
\text { length, ICU support, need } \\
\text { for a mechanical venti- } \\
\text { lator, and mortality didn't } \\
\text { differ significantly in the } \\
\text { intervention group } \\
\text { compared to the compar- } \\
\text { ator group }\end{array}$ \\
\hline $\begin{array}{l}\text { Oliveira et al. } \\
\text { [41] }\end{array}$ & $\begin{array}{l}\text { Retrospective, } \\
\text { observational, } \\
\text { Case series study }\end{array}$ & $\begin{array}{l}\text { Intervention: } \\
15\end{array}$ & $\begin{array}{l}\text { COVID-19 patients } \\
\text { with encephalopathy }\end{array}$ & $\begin{array}{l}500 \text { mg intravenous } \\
\text { thiamine three times a } \\
\text { day for five days }\end{array}$ & Not applicable & $\begin{array}{l}\text { Improved neurological } \\
\text { outcomes in the inter- } \\
\text { vention group (73\%) }\end{array}$ \\
\hline $\begin{array}{l}\text { Rastogi et al. } \\
\text { [6] }\end{array}$ & $\begin{array}{l}\text { Placebo- } \\
\text { controlled, } \\
\text { randomized trial }\end{array}$ & $\begin{array}{l}\text { Intervention: } \\
16 \\
\text { Comparator: } \\
24\end{array}$ & $\begin{array}{l}\text { Asymptomatic or } \\
\text { mildly symptomatic } \\
\text { COVID-19 patients } \\
\text { with hypovitaminosis } \\
\text { D }\end{array}$ & $\begin{array}{l}60,000 \mathrm{IU} \text { oral chole- } \\
\text { calciferol for seven } \\
\text { days with therapeutic } \\
\text { target of } 25(\mathrm{OH}) \\
\text { D }>50 \mathrm{ng} / \mathrm{mL}\end{array}$ & Placebo & $\begin{array}{l}\text { There was a significant } \\
\text { decrease in fibrinogen } \\
\text { level in the intervention } \\
\text { group compared to the } \\
\text { comparator group }\end{array}$ \\
\hline $\begin{array}{l}\text { Sabico et al. } \\
\text { [97] }\end{array}$ & $\begin{array}{l}\text { Open-label, ran- } \\
\text { domized, and } \\
\text { controlled trial }\end{array}$ & $\begin{array}{l}\text { Intervention: } \\
36 \\
\text { Comparator: } \\
33\end{array}$ & $\begin{array}{l}\text { Mild to moderate } \\
\text { COVID-19 patients } \\
\text { with sub-optimal } \\
\text { vitamin D level }\end{array}$ & $\begin{array}{l}5,000 \text { IU oral vitamin } D_{3} \\
\text { daily for two weeks }\end{array}$ & $\begin{array}{l}1,000 \text { IU oral } \\
\text { vitamin } D_{3} \\
\text { daily for two } \\
\text { weeks }\end{array}$ & $\begin{array}{l}\text { Reduced recovery time in } \\
\text { the intervention group } \\
\text { (six days) compared to } \\
\text { the comparator group } \\
\text { (seven days) }\end{array}$ \\
\hline $\begin{array}{l}\text { Siahkali } \\
\text { et al. [98] }\end{array}$ & $\begin{array}{l}\text { Open-label, ran- } \\
\text { domized, and } \\
\text { controlled trial }\end{array}$ & $\begin{array}{l}\text { Intervention: } \\
30 \\
\text { Comparator: } \\
30\end{array}$ & $\begin{array}{l}\text { Severe COVID-19 } \\
\text { patients }\end{array}$ & $\begin{array}{l}6 \mathrm{~g} \text { daily high-dose } \\
\text { intravenous vitamin C }\end{array}$ & $\begin{array}{l}\text { No adjunctive } \\
\text { intervention }\end{array}$ & $\begin{array}{l}\text { The outcomes didn't } \\
\text { differ in the intervention } \\
\text { group compared to the } \\
\text { comparator group. }\end{array}$ \\
\hline $\begin{array}{l}\text { Sulaiman } \\
\text { et al. [43] }\end{array}$ & $\begin{array}{l}\text { Retrospective, } \\
\text { observational, } \\
\text { and cohort study }\end{array}$ & $\begin{array}{l}\text { Intervention: } \\
88 \\
\text { Comparator: } \\
650\end{array}$ & $\begin{array}{l}\text { Critically ill COVID-19 } \\
\text { patients }\end{array}$ & $\begin{array}{l}\text { The median } 100 \mathrm{mg} \\
(50-200 \mathrm{mg} \text { ) thiamine } \\
\text { for a median duration of } \\
\text { seven days ( } 5-12 \text { days) }\end{array}$ & $\begin{array}{l}\text { No adjunctive } \\
\text { intervention }\end{array}$ & $\begin{array}{l}\text { The lower in-hospital } \\
\text { mortality rate in the } \\
\text { intervention group } \\
(18.4 \%) \text { compared to the } \\
\text { comparator group } \\
(38.7 \%) \text { and lower } \\
\text { incidence of thrombosis } \\
\text { during ICU stay in the } \\
\text { intervention group ( } 2.4 \%) \\
\text { compared to the compar- } \\
\text { ator group }(11.1 \%)\end{array}$ \\
\hline $\begin{array}{l}\text { Tan et al. } \\
{[73]}\end{array}$ & $\begin{array}{l}\text { Retrospective, } \\
\text { observational, } \\
\text { and cohort study }\end{array}$ & $\begin{array}{l}\text { Intervention: } \\
17 \\
\text { Comparator: } \\
26\end{array}$ & Not reported & $\begin{array}{l}\text { Combination of } \\
1,000 \text { IU oral vitamin } \\
\text { D3, } 150 \mathrm{mg} \text { oral } \\
\text { magnesium, and } 500 \\
\text { mcg oral vitamin B12 } \\
\text { daily upon admission }\end{array}$ & $\begin{array}{l}\text { No adjunctive } \\
\text { intervention }\end{array}$ & $\begin{array}{l}\text { The lower need for ICU } \\
\text { support in the interven- } \\
\text { tion group ( } 5.9 \%) \\
\text { compared to the compar- } \\
\text { ator group }(30.8 \%) \text { and } \\
\text { lower need for oxygen } \\
\text { therapy in the interven- } \\
\text { tion group ( } 17.6 \%) \\
\text { compared to the compar- } \\
\text { ator group }(61.5 \%)\end{array}$ \\
\hline $\begin{array}{l}\text { Thomas } \\
\text { et al. [99] }\end{array}$ & $\begin{array}{l}\text { Open-label, ran- } \\
\text { domized, and } \\
\text { controlled trial }\end{array}$ & $\begin{array}{l}\text { Intervention: } \\
164 \\
\text { Comparator: } \\
50\end{array}$ & $\begin{array}{l}\text { Ambulatory COVID-19 } \\
\text { patients }\end{array}$ & $\begin{array}{l}\text { Either } 50 \mathrm{mg} \text { zinc } \\
\text { gluconate, } 8,000 \mathrm{mg} \\
\text { ascorbic acid, or their } \\
\text { combination for } \\
10 \text { days }\end{array}$ & Standard care & $\begin{array}{l}\text { The duration of symptoms } \\
\text { didn't differ in the inter- } \\
\text { vention group compared } \\
\text { to the comparator group }\end{array}$ \\
\hline
\end{tabular}


Table 1: (continued)

\begin{tabular}{|c|c|c|c|c|c|c|}
\hline Study & Design & Sample size & Clinical classification & Intervention & Comparator & Outcomes \\
\hline $\begin{array}{l}\text { Zhang et al. } \\
{[100]}\end{array}$ & $\begin{array}{l}\text { Placebo- } \\
\text { controlled, } \\
\text { double-blind ran- } \\
\text { domized trial }\end{array}$ & $\begin{array}{l}\text { Intervention: } \\
27 \\
\text { Comparator: } \\
29\end{array}$ & $\begin{array}{l}\text { Critically ill COVID-19 } \\
\text { patients }\end{array}$ & $\begin{array}{l}12 \mathrm{~g} \text { intravenous } \\
\text { vitamin } \mathrm{C} / 50 \mathrm{~mL} \text { every } \\
12 \mathrm{~h} \text { for seven days at a } \\
\text { rate of } 12 \mathrm{~mL} / \mathrm{h}\end{array}$ & Placebo & $\begin{array}{l}\text { The invasive mechanical } \\
\text { ventilation-free days in } \\
28 \text { days in the interven- } \\
\text { tion group didn't differ } \\
\text { compared to the compar- } \\
\text { ator group, but the } \\
\text { oxygenation ( } \mathrm{PaO} 2 / \mathrm{FiO} 2) \\
\text { was improved, and the } \\
\text { IL-6 level was reduced in } \\
\text { the intervention group. }\end{array}$ \\
\hline $\begin{array}{l}\text { Zhao et al. } \\
\text { [101] }\end{array}$ & $\begin{array}{l}\text { Retrospective } \\
\text { before-after case- } \\
\text { matched study }\end{array}$ & $\begin{array}{l}\text { Intervention: } \\
55 \\
\text { Comparator: } \\
55\end{array}$ & $\begin{array}{l}\text { Moderate COVID-19 } \\
\text { patients }\end{array}$ & $\begin{array}{l}100 \mathrm{mg} / \mathrm{kg} \text { daily intra- } \\
\text { venous vitamin C for } \\
\text { seven days at a rate of } \\
1 \mathrm{~g} / \mathrm{h} \text { since admission }\end{array}$ & $\begin{array}{l}\text { No adjunctive } \\
\text { intervention }\end{array}$ & $\begin{array}{l}\text { The lower incidence and } \\
\text { duration of SIRS in the } \\
\text { intervention group } \\
\text { (9.5\%-2days) compared } \\
\text { to the comparator group } \\
\text { ( } 45.4 \%-6 \text { days) on day } 7 \\
\text { The intervention group } \\
\text { had lower CRP levels, } \\
\text { improved coagulation } \\
\text { factors, and more } \\
\text { CD4 }{ }^{+} \text {T cells compared to } \\
\text { the comparator group. }\end{array}$ \\
\hline
\end{tabular}

et al. administered $24 \mathrm{~g}$ per day in the form of $12 \mathrm{~g}$ of vitamin $\mathrm{C} / 50 \mathrm{~mL}$ every $12 \mathrm{~h}$ for seven days at a rate of $12 \mathrm{~mL} / \mathrm{h}$, which was consistent with these findings. Although they did not find noteworthy results in terms of extending invasive mechanical ventilation-free days in 28 days, they did uncover better $\mathrm{PaO} 2 / \mathrm{FiO} 2$ and, as a consequence, improved oxygenation for critically ill patients [100].

Aside from a poor diet, several factors are associated with depleted vitamin C levels, which enhance susceptibility to COVID-19 owing to insufficient micronutrient levels for appropriate immunological and organ function. These factors consist of gender, comorbidities, and obesity. According to the research, vitamin $\mathrm{C}$ serum/plasma concentrations are greater in women than in men (24-26), and males have considerably higher rates of deficiency, which is adversely related to $\mathrm{C}$ serum level the lower serum level of vitamin $\mathrm{C}$ might be other reason for worse outcome in males than females with COVID-19 [57]. Furthermore, there is a welldocumented negative connection between serum $\mathrm{C}$ level and obesity. Considering these criteria while administering adequate doses of the vitamin may contribute to improved outcomes for patients [114].

\section{Vitamin D}

The significance of vitamin D in cases of respiratory infection is demonstrated by the fact that low vitamin D levels are widespread throughout the world population and have been linked to an increased risk of pneumonia [115]. Evidence suggests that low serum vitamin D levels are associated with an increased risk of high burdens of viral infections [116]. Regarding vitamin D's immune-modulatory effects, the efficacy of its supplementation in patients with infectious disease, particularly vitamin D-deficient individuals, cannot be overlooked [115]. Several studies have been conducted (Table 1) to validate vitamin D's prophylactic and therapeutic relevance in COVID-19 patients. According to Luo et al., serum 25(OH)D concentrations are substantially lower in severe COVID-19 patients than in nonsevere patients. It was observed that vitamin D deficiency was associated with COVID-19 severity, after adjusting for several potential confounders, such as age, sex, comorbidities, body mass index (BMI), and smoking status. Interestingly, it was shown in the same study that $25(\mathrm{OH}) \mathrm{D}$ concentrations in the death group were lower than those in the discharged group (18.7 vs. $23.2 \mathrm{nmol} / \mathrm{L}$ ) [117]. Regarding a recent clinic-based cohort study of 185 COVID-19 patients, regardless of age, gender, and comorbidities, the risk of invasive mechanical ventilation or death (primary endpoint) among patients with adequate vitamin D levels was nearly $80 \%$ lower. Likewise, over $90 \%$ of mortality in this group was statistically linked to vitamin D deficiency [118]. Several studies on the impact of vitamin D deficiency on COVID-19 incidence and poor outcomes found an inverse relationship between vitamin D 
levels and susceptibility to COVID-19 and its severe implications. As a result, individuals with vitamin D deficiency are considered a high-risk category for disease incidence and must be supplemented with vitamin $\mathrm{D}$ to meet current requirements, given that current standards have been defined addressing the requirements of bone [119]. Given the complex correlation between vitamin $\mathrm{D}$ and viral infections rather than immune function, elucidating how vitamin $\mathrm{D}$ imposes its impacts on COVID-19 patients is crucial; it is suggested that vitamin D supplementation in the COVID-19 pandemic, even in vitamin D-replete individuals, is worth consideration [120]. Taken together, evidence supports the notion that there is a strong relationship between low vitamin D and COVID-19 severity. Since vitamin D is important for immune system regulation and antiviral activities [121]. Cell junctions are the body's initial line of defense against infections, and they can be disrupted by several viruses, namely SARS-CoV-2 [122]. Vitamin D and its receptor can preserve tissue barrier integrity since there is a connection between vitamin $\mathrm{D} /$ vitamin $\mathrm{D}$ receptors (VDR) signaling and tissue barrier integrity. VDRs are expressed in nearly all tissues, including endothelial cells, vascular smooth muscles, and cardiomyocytes [123]. The ligandbound VDR is a transcriptional factor that binds to the promoter region of target genes and modulates the expression of the specific genes, which has been found to be associated with persuading NO synthesis through endothelial nitric acid synthase (eNOS) bioactivity. It is essential in mediating angiogenesis by enhancing endothelial cell migration [124]. Moreover, it can maintain the formation of capillary-like structures in human umbilical endothelial cells (HUVEC) and the human coronary artery [125]. It has been reported in the literature that it can persuade cell migration and proliferation by upregulating gene expression of matrix metalloproteinase 2 (MMP-2) and an extracellular matrix dissolving factor. The rigidity of tight junctions, particularly in the pulmonary tissue, has been shown to be an effective preventative factor against immune cell infiltration, which contributes to the development of severe pneumonia and ARDS in COVID-19 patients [124] (Figure 1).

It is well understood that virus clearance by the host at the onset of infection is critical; otherwise, the virus will infiltrate tissues with high ACE2 receptor expression, such as the lungs and kidneys, causing inflammation mediated by the innate immune system, specifically through the release of pro-inflammatory cytokines by macrophages and Th1 cells [126]. As angiotensin (Ang) II levels in individuals with adequate $25(\mathrm{OH}) \mathrm{D}$ levels $(30 \mathrm{ng} / \mathrm{mL})$, insufficiency $(15-29.9 \mathrm{ng} / \mathrm{mL})$, and the deficiency $(15 \mathrm{ng} / \mathrm{mL})$ were compared, it was suggested that vitamin D sufficient individuals had greater circulating Ang II levels. Conversely, individuals with vitamin D deficiency exhibited significantly slower renal plasma flow responses to Ang II infusion
[127]. In this way, its interaction with ACE2 in COVID-19 patients is an issue worth considering. Inadequate vitamin D levels may activate the RAS, which can lead to chronic cardiovascular disease and reduced lung function by triggering lung fibrosis [127]. SARS-CoV-2 activates A disintegrin and metalloproteinase 17 (ADAM17), which suppresses not only ACE2 expression but also the ACE2/Ang 1-7/Mas axis, enabling the virus to enter the cell more readily. This leads to an increase in Ang II, which in turn upregulates ADAM 17. This leads to the rise in Ang II, which upregulates ADAM17. Lung damage, myocardial injury (heart failure), and vascular damage (fatal thrombosis) are all possible outcomes of this procedure. Active vitamin D can interfere with ACE2-angiotensin 1-7-ADAM17, which promotes ACE2 synthesis meanwhile restricting Ang II synthesis [128, 129]. Vitamin D's renoprotective function is largely attributed to its inhibition of ACE2 expression in the kidney, according to studies on patients with kidney disease [130, 131]. $1,25(\mathrm{OH})_{2} \mathrm{D}$ can alleviate LPS-induced acute lung injury; therefore, through this mechanism, vitamin D supplementation can be accompanied by patients' survival [132]. The evidence shows that vitamin D analog calcitriol enhances ACE2 expression in the lungs, which can facilitate viral binding to the pulmonary epithelium. According to research, $1,25(\mathrm{OH})_{2} \mathrm{D}_{3}$ can decrease renin gene expression by binding to the transcription factor cyclic adenosine monophosphate (CAMP) response element-binding (CREB) protein, leading to reduced cAMP response element activity in the renin gene promoter [133]. It may be followed by a decrease in Ang II production, resulting in less pulmonary vasoconstriction [133]. Although vitamin D increases the expression of ACE2, it limits the pulmonary vasoconstriction response in COVID-19 patients, which is a paradoxical impact of vitamin D [131]. As in COVID-19 patients ACE2 is disturbed during infection and Ang II is supposed to be converted by ACE2, it starts to accumulate leading to severe outcomes of disease related to over-activated proinflammatory responses including ARDS, myocarditis, or cardiac injury [131]. So, in COVID-19 patients, vitamin D supplementation reduces pro-inflammatory cytokine production by hindering renin release [131]. However, since both vitamin D and ACE2 are considered to be negative RAS mediators, evidence suggests that ACE2 may have distinct effects on COVID-19 patients at the same time. ACE2 expression is linked with the development of severe COVID-19, even though it regulates the RAS. These findings raise the challenge of whether antiviral medications that impact ACE2 are effective for these patients or if they might aggravate their condition. The optimal time and dosage of vitamin D for therapeutic approaches are prominent once evaluating SARS-CoV-2 infection as three stages [134, 135]. 


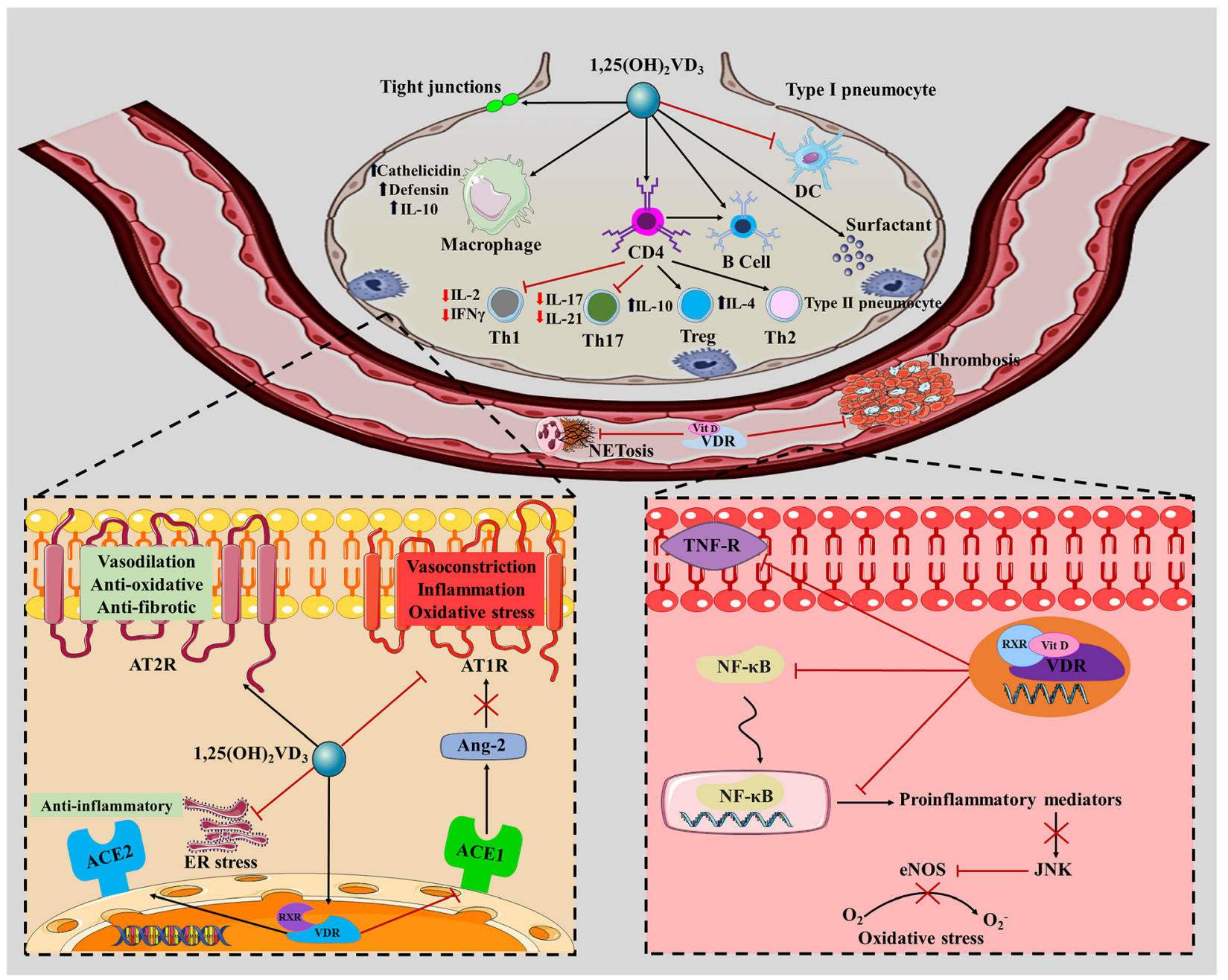

Figure 1: Vitamin D has a twofold effect on the immune system and inflammation.

Vitamin D appears to boost the immune responses in the battle between host and virus by regulating some key elements in infected cells such as ER stress. This vitamin regulates immune responses by suppressing proinflammatory environment and increasing secretion of anti inflammatory cytokines. It additionally suppresses T cell proliferation which results in a shift from a Th1 to a Th2 phenotype, meanwhile it provokes macrophage differentiation, inhibit DCs maturation, and promotes immuno-regulatory functions of Tregs. Vitamin D has antifibrotic effect and can increase vasodilation via increasing ACE2 expression, and decreasing ACE1 expression. Furthermore, $1,25(\mathrm{OH})_{2} \mathrm{D}_{3}$ is known to suppress the NF-KB pathway, resulting in the prevention of oxidative stress, which ultimately inhibits formation of blood clots and endothelial dysfunction. ER, Endoplasmic reticulum; ACE, angiotensin-converting enzyme; VDR-RXR, Vitamin D receptor/retinoic acid X receptor; NF-KB, Nuclear factor kappa-B; Ang-2, Angiotensin-2; IL, Interleukin; AT1R, Angiotensin receptor type 1; DC, Dendritic cell; Th, Thelper; IFN $\gamma$, Interferon gamma; eNOS, Endothelial nitric acid synthase; JNK, C-jun kinase; TNF-R, Tumor necrosis factor-receptor; NET, Neutrophil extracellular trap.

Serum 25(OH)D levels are positively correlated with serum C-reactive protein (CRP) levels whereas neutrophil and lymphocyte counts are negatively correlated. Therefore, increased inflammation underlies the fact that low serum vitamin D levels increase the severity of the disease and mortality. Vitamin D, like tocilizumab, appears to regulate the activity of an IL-6, lowering the acute-phase response linked to increased lung injury and complications such as ARDS or sepsis [136].

Since VDRs are expressed on B cells, T cells, and antigen-presenting cells (APCs) of the immune system, these cells produce the active vitamin D metabolite, which has a remarkable connection with autocrine activities of the local immunologic milieu [16]. Studies demonstrate that $1,25(\mathrm{OH})_{2} \mathrm{VD}_{3}$ inhibits over-activated immune responses through a variety of mechanisms, which are mainly mediated via the memory $\mathrm{T}$ cell compartment due to the greater expression of VDR on these cells compared to naive T cells [9]. The attachment of the vitamin D receptor/ retinoic acid X receptor (VDR-RXR) complex to the VDR in the promoter of genes encoding IL-2 and IFN $y$ by $1,25(\mathrm{OH})_{2} \mathrm{VD}_{3}$ inhibits the production of IL-2 and IFN $y$ [137]. 
Vitamin D controls immune responses and the COVID19-induced cytokine storm, which is linked to various clinical multi organ complications of COVID-19, by modulating $\mathrm{T}$ cell proliferation via $\mathrm{T}$ cell VDR. $1,25(\mathrm{OH})_{2} \mathrm{VD}_{3}$ suppresses $\mathrm{T}$ cell proliferation by reducing IL-2 production, which plays an important role in cell proliferation [138]. T cell proliferation inhibition causes a shift from a Th1 to a Th2 phenotype, in which decreased Th1 immune responses and increased Th2 immune responses stimulate anti-inflammatory responses and avoid their deleterious effects by inhibiting them [16]. Since Th1 produces proinflammatory cytokines while Th2 produces anti-inflammatory cytokines, vitamin D inhibits Th1 proliferation besides promoting Th2 and Treg production, resulting in reduced and regulated proinflammatory responses, primarily by reducing IL-6 and increasing production of anti inflammatory cytokines such as IL-10. It is a major target for cytokine storm management, particularly in COVID-19 [16, 139]. $1,25(\mathrm{OH})_{2} \mathrm{VD}_{3}$ inhibits the production of inflammatory cytokines including IL-1, IL-6, IL-8, IL-12, and TNF $\alpha$ by suppressing monocytes and it affects dendritic cell (DC) differentiation and maturation by reducing the major histocompatibility complex (MHC) MHC class II molecules, costimulatory molecules, and IL-12 [9]. As a result, improved vitamin D status in COVID-19 patients is directly connected to COVID-19-induced manifestations, particularly in severely infected individuals [140]. $1,25(\mathrm{OH})_{2} \mathrm{VD}_{3}$, on the other hand, has the ability to suppress $\mathrm{T}$ cell function by increasing nonspecific $\mathrm{T}$ cell suppressor activity, resulting in decreased lymphocyte reactivity and cytotoxic $\mathrm{T}$ cell responses [9, 141]. Furthermore, $1,25(\mathrm{OH})_{2} \mathrm{VD}_{3}$ suppresses B cell proliferation while disrupting differentiation and function, resulting in Ig suppression and modulation [16]. In addition, $1,25(\mathrm{OH})_{2} \mathrm{VD}_{3}$ contributes to inhibit and modulate the immune responses of DCs and monocytes [9]. As a result, $1,25(\mathrm{OH})_{2} \mathrm{VD}_{3}$ and its analogs have been demonstrated to be effective in the treatment of inflammatory and autoimmune diseases [142, 143]

Moreover, it is well known that ROS are formed in a variety of inflammatory diseases, and that increased ROS release causes damage to various organs and tissues, which may be mitigated owing to vitamin D's anti oxidant properties [144]. According to the evidence, paricalcitol serves as a ligand for VDR and is analogous to vitamin D. It protects the kidneys in spontaneously hypertensive rats by limiting NOX activity and avoiding mitochondrial injury (pro oxidative enzyme). In renal cortex cells from these animals, these alterations were mediated by an increase in intracellular levels of heat shock protein 70 and a decrease in Ang II type 1 receptors [144].

In acute viral respiratory infections, vitamin $\mathrm{D}$ acts as an immunomodulatory component of the innate immune system by upregulating cytochrome P450 family 27 subfamily B member 1 (CYP27B1) in respiratory epithelial cells altering gene expression in innate immune cells such as macrophages, monocytes, and DCs, which contain all the necessary characteristics such as CYP27B1enzyme and VDR resulting in the formation of $1,25(\mathrm{OH})_{2} \mathrm{D}_{3}$ from an inactive form of locally stored vitamin $\mathrm{D}$ and subsequent regulated immune responses to limit further damage caused by overactivated immune responses while retaining antiviral activities against pathogens [145]. According to a study by Zhang and colleagues, vitamin $\mathrm{D}$ can protect against endothelial dysfunction (ED) by reducing oxidative stress and NF- $\mathrm{kB}$ activation [146]. It has been demonstrated in research by Liu et al. that vitamin D effectiveness in Mycobacterium tuberculosis is mediated by both VDR and CYP27B1 of activated macrophages, leading to the synthesis of antimicrobial peptides (AMPs), including molecules known as cathelicidins and defensins [147]. These are antimicrobial peptides that have been linked to the direct pathogen killing or endotoxin binding via activating ion channels and permeable membranes [148]. Cathelicidin has also been shown to be generated in lung injuries by respiratory epithelial cells expressing CYP27B1 converting the inactive form of vitamin D to the active form [145]. Despite the lack of data on the effects of vitamin D on NK cells in COVID-19 patients, it has been illustrated that low levels of vitamin D in serum correlate with reduced NK activity in patients with chronic disease. It posits a link between vitamin $\mathrm{D}$ and enhanced cytotoxicity and exocytosis of NK cells $[145,149]$.

Additionally, in diseases with neurological complications as COVID-19, vitamin D potency in neuroprotective functions is considerable. Vitamin D interacts with neutrophin, which is linked to ischemic brain injuries and neurodegenerative diseases, to alter nerve cell differentiation and preservation in the peripheral nervous system (PNS) and CNS [150, 151].

Clinicians might consider vitamin D administration because of its effective prophylactic and restorative action against COVID-19 [145, 152]. According to COVID-19 medical data, these patients' nutrition levels have been alleviated to some extent. Vitamin D deficiency is the most frequent, with $76 \%$ of patients having a deficit ( $\leq 20 \mathrm{ng} / \mathrm{dL}$ ) and $24 \%$ having a severe deficiency $(\leq 10 \mathrm{ng} / \mathrm{dL})[120,153]$. Regarding the other nutrients, it is yet unknown if individual nutrient deficiencies influence immunity or whether nutrient deficiency worsens a patient's overall condition; hence, vitamin D deficiency is regarded as both a possible risk factor and underlying condition in COVID-19 patients $[154,155]$. Some randomized trials are evaluating the role of vitamin D in COVID-19 infections and severities that have 
yet to be disclosed. In a study by Karahan Adata et al., the relationship between vitamin $\mathrm{D}$ deficiency and the prognosis of COVID-19 has been suggested [156]. In hospitalized moderate-to-severely ill COVID-19 patients, vitamin D deficiency/insufficiency was particularly abundant. The mean level of 25(OH)D was $15.2 \pm 10.3 \mathrm{ng} / \mathrm{mL}$. As COVID-19 severity increased, the level of $25(\mathrm{OH}) \mathrm{D}$ was further reduced [157]. It is demonstrated that there is a negative correlation between serum 25( $\mathrm{OH})$ vitamin $\mathrm{D}$ level and age $(\mathrm{r}=-0.3, \mathrm{p}<0.001)$. Thus, it can be speculated that disproportionately severe clinical outcomes seen in the elderly may be partly due to age-related vitamin D deficiency [157].

There is a lot of debate over what is deemed "normal" or "optimal" serum 25(OH)D levels. However, many scientists and doctors prefer to adopt the lower bound of acceptable vitamin D status of $30 \mathrm{ng} / \mathrm{mL}(75 \mathrm{nmol} / \mathrm{L})$, as proposed by the Endocrine Society, and some have also advised, in light of the COVID-19 pandemic, to reach and maintain $30 \mathrm{ng} / \mathrm{mL}$ levels at least in the elderly or in Citizens of nations with a high incidence of vitamin D insufficiency, notably COVID-19 patients at high risk of intensive care unit hospitalization. Others, on the other hand, recommended a range of $40-60 \mathrm{ng} / \mathrm{mL}$ as an optimal range for human health, claiming that such levels might lower the risk of certain infections (influenza, various coronavirus infections, etc.) as well as cancer, diabetes, rheumatic diseases, and pregnancy complications [158].

Vitamin D levels greater than $30 \mathrm{ng} / \mathrm{mL}$ have been attributed to a substantial reduction in SARS-CoV-2 infection severity and mortality [157]. As shown in a prior metaanalysis, in comparison to individuals with serum 25(OH)D concentrations $>25 \mathrm{nmol} / \mathrm{L}$, the protective impact of vitamin $\mathrm{D}$ was higher in subjects with baseline serum 25(OH)D levels $25 \mathrm{nmol} / \mathrm{L}$ [159]. Vitamin D supplementation of 20-50 $\mu \mathrm{g} /$ day (800-1,000 IU) had formerly been regarded to be safe. Adults who take up to $100 \mu \mathrm{g}$ of vitamin D per day (4,000 IU) have been revealed to have no adverse effects [120]. Some researchers have discovered that taking a vitamin D supplement at a dosage of $100-250 \mu \mathrm{g} / \mathrm{day}$ $(4,000-10,000)$ for six weeks raises the baseline serum concentration of $25(\mathrm{OH}) \mathrm{D}$ by two-three folds, with no side effects. According to the research, taking up to $250 \mu \mathrm{g} / \mathrm{day}$ for a month can raise serum 25(OH)D levels to the optimal range of $75-125 \mathrm{nmol} / \mathrm{L}$. After a month, the dosage can be lowered to $100 \mu \mathrm{g} /$ day to maintain circulating $25(\mathrm{OH}) \mathrm{D}$ concentrations [160]. According to the findings of a study, a single dosage of 600,000 IU vitamin D can raise D3 serum to $25(\mathrm{OH}) \mathrm{D}$ to $>30 \mathrm{ng} / \mathrm{mL}$ in elderly individuals for at least four weeks without triggering any side effects [161]. However, a systematic review found that supplementing with a high dose of vitamin D, about 100,000 IU, failed to raise
25(OH)D levels over $30 \mathrm{ng} / \mathrm{mL}$, Ashu Rastogi's study recommended a daily cholecalciferol dosage of 60,000 IU (420,000 IU for the first week) [6]. It's greater than current standards, but it's been shown to be safe, with no indications of hypercalcemia. This study endorses the safety of taking large dosages of vitamin $\mathrm{D}$ for a short period. The literature review shows that vitamin D supplementation appears to lower the risk of SARS-CoV-2 infection and may result in early viral clearance [153]. Furthermore, research shows that supplementing with $300,000 \mathrm{IU}$ vitamin D for COVID-19 patients who are not in the ICU can reduce symptoms; nevertheless, the majority of studies imply that vitamin D supplementation does not affect the length of hospitalization $[6,162,163]$.

In terms of vitamin D's initial role in regulating inflammation, it increases the asymptomatic carriage state while decreasing symptomatic implications in these patients [119]. Vitamin D may be an effective therapy for anticoagulant individuals who are experiencing bleeding issues. Hejazi et al. demonstrated that vitamin $\mathrm{D}$ supplementation allowed for a reduced warfarin dosage regimen and was linked with fewer adverse reactions in those with thromboembolism [164]. Vitamin D or its analogs have been shown in previous researches to reduce the expression of tissue factors such as prothrombotic plasminogen activator inhibitor1 and thrombospondin1, while increasing the expression of thrombomodulin. Thus, it appears that a sufficient dose of vitamin D may help to minimize the risk of thrombosis. Even though larger studies haven't ever identified significant variations in COVID-19 patients' coagulopathy between vitamin D treatment and the control group, further research is required to determine a definitive link between vitamin D supplementation and COVID-19-induced coagulopathies [165].

Notably, Lemke et al. claimed that irregular coagulation in individuals with severe COVID-19 is "consumptive." The authors further proposed that, in addition to depleting key coagulation factors, clinical manifestations of improper clotting in many serious COVID-19 patients consume a vital anticoagulant, protein S [166]. Protein S levels were found to be low in a cohort study performed at Colentina University Hospital in Romania. As a result, any increase in vitamin D's anticoagulant activity will be advantageous to those individuals [167].

It is proposed to conduct magnesium supplementation coupled with vitamin D supplements. Magnesium facilitates vitamin D-related processes. All the enzymes that metabolize vitamin D seem to require magnesium, which is an essential cofactor for vitamin D synthesis and leads to increased intestinal absorption of vitamin D. The proper dose of magnesium for maintaining hemostasis like the stability of cell function, RNA and DNA synthesis, and cell 
repair, as well as maintaining the cell's antioxidant status, should be in the range of $250-500 \mathrm{mg} /$ day $[168,169]$. Even though in this large-scale MR study, no evidence was found to support increasing 25(OH)D levels.

\section{Vitamin E}

Vitamin E is a dietary lipophilic antioxidant that preserves polyunsaturated fatty acids (PUFAs) in the membrane from oxidation while also regulating the production of ROS, reactive nitrogen species (RNS), and signal transduction [170]. Vitamin E (alpha-tocopherol) has been demonstrated to be an effective antiferroptosis agent that compensates for a lack of various antioxidants, namely glutathione peroxidase 4, through inhibiting 15-lipoxygenase owing to its antioxidant characteristic. It inhibits 15 -lipoxygenase by reduction of the non-heme iron of the enzyme from its active $\mathrm{Fe}^{3+}$ form to the $\mathrm{Fe}^{2+}$ form $[171,172]$. Ferroptosis is a kind of programmed cell death that is linked to inflammation, neurodegeneration, or, more generally, multi organ failure. Ferroptosis has been attributed to multi-organ damage in COVID-19 patients, indicating that vitamin $\mathrm{E}$ supplementation in these patients might provide positive benefits. As a result, supplementation with a high dose of $500 \mathrm{mg} / \mathrm{kg}$ vitamin $\mathrm{E}$ might serve a protective role against multi organ complications in these patients [173]. Likewise, vitamin $\mathrm{E}$ depletion has been found to trigger lipid peroxidation, which has been substantiated an inverse correlation between vitamin $\mathrm{E}$ and plasma lipoperoxidase levels [174]. Its deficiency also has been suggested to contribute to gene mutations that enhance virulence in various viruses, including influenza and SARS-CoV-2 [175].

Vitamin $\mathrm{E}$ is an immunomodulator agent that has been widely known to be involved in various aspects of the immune system which exert its effects via multiple pathways that have been found to be well-associated with the immune response to different pathogens including SARS-CoV-2. It downregulates prostaglandin E2 (PGE2) and cyclooxygenase-2 (COX-2) through attenuating nitrogen oxides formation to modulate inflammatory responses. It also regulates Th1/Th2 ratio while also initiating naive T-lymphocyte synapse formation and activation signals [176, 177]. Furthermore, vitamin E boosts humoral immune responses. According to Broome et al., individuals over the age of 65 who were administered 60 or $200 \mathrm{mg}$ daily vitamin $\mathrm{E}$ had a higher humoral immune response to poliovirus and fewer mutant viral strains as compared to those in the placebo group $[178,179]$. It underpins the debate about whether vitamin
E supplementation can improve the efficacy of the COVID-19 vaccination.

\section{Vitamin K}

Although little is known regarding the possible benefits of taking vitamin $\mathrm{K}$ to improve COVID-19 outcomes, it is widely known that individuals with severe COVID-19 experience prominent symptoms of coagulopathy and thrombosis [180]. Elastic fibers are key components of the extracellular matrix of the lungs, where matrix Gla protein (MGP) is abundantly expressed [181]. As a result, MGP appears to have a similar role in the pulmonary compartment as it does in the vasculature, and it is critical for the preservation of elastic fibers against calcification. Complications with MGP activation may be linked to the degradation of elastic fibers. Mineralization occurs more frequently in elastic fibers that have been partially degraded. Additionally, the release of matrix metalloproteinases (MMPs) may accelerate the calcification of elastic fibers, leading to lung fibrosis [182].

COVID-19 patients demonstrated a substantial increase in extrahepatic inactive MGP, indicating a menaquinone-7 (MK-7) deficit. Furthermore, a subset of pulmonary macrophages that synthesize MMPs seems to be augmented during severe SARS-CoV-2 pneumonia, leading to elastic fiber degradation [181, 183]. Accelerated elastic fiber breakdown and insufficient active MGP in COVID-19 patients indicate a correlation between MK-7 deficiency and COVID-19. As a result, COVID-19 may hypothetically be related to MK-7 deficiency [181]. In line with these findings, it is reported that plasma dephosphorylated-uncarboxylated matrix Gla-protein (dp-ucMGP) has a significant cross-sectional correlation with kidney function, with circulating dpucMGP rising with decreasing renal function, which is a complication of $32-46 \%$ of COVID-19 patients [184].

It is hypothesized that the vitamin $\mathrm{K}$ deficiency during the early stages of COVID-19 infection may contribute to the activation of the Th2 storm, resulting in higher output in the presence of CRP and IL- 6 vitamin K deficiency is frequently observed in COVID-19 patients and that the deficit is greater in males than in females [185]. Furthermore, in male patients, vitamin K deficiency is coupled with a greater IL-6 level in the general circulation [186]. It is also speculated that vitamin K deficiency has a contribution to other COVID-19-specific clinical manifestations. Although dp-ucMGP is raised in COVID-19, hepatic procoagulant and vitamin $\mathrm{K}$ status, assessed by protein induced by vitamin $\mathrm{K}$ absence-II (PIVKA-II) did not differ [182]. Endothelial cells are responsible for approximately $50 \%$ of protein S synthesis. The preferential activation of 
hepatic proteins over extrahepatic proteins suggests that the uncarboxylated protein $\mathrm{S}$ fraction will rise, increasing the risk of thrombosis [182].

Concerning vitamin $\mathrm{K}$ deficit in COVID-19 patients, caution is advised while using vitamin $\mathrm{D}$ in a state of vitamin $\mathrm{K}$ deficiency, because vitamin $\mathrm{D}$ intake in these instances may jeopardize pulmonary and vascular health. Several studies have raised concerns that vitamin D administration is linked to premature death among vitamin K-deficient stable kidney transplant recipients [187]. It may thus be appropriate to initially supply vitamin $\mathrm{K}$ is always vitamin K-deficient COVID-19 hospitalized patients and to begin vitamin $\mathrm{D}$ administration only after extrahepatic vitamin $\mathrm{K}$ status has been restored in those who are vitamin D-deficient coagulation is a common complication of COVID-19 which is ensued by the direct function of endothelial cells [181]. Indeed, they secrete coagulation inhibitors such as protein $\mathrm{S}$ and serve as receptors for anticoagulant proteins found in the blood that interfere with clot formation (like protein $\mathrm{C}$ ). Thus, the imbalance of the coagulation system by lysing endothelial cells following infection might make a significant contribution to thrombosis [188].
Vitamin Kantagonists (VKAs), such as warfarin, are still extensively employed as anticoagulant medications [189] (Figure 2). VKAs disrupt the vitamin $\mathrm{K}$ cycle by blocking vitamin $\mathrm{K}$ 2,3-epoxide reductase, resulting in vitamin $\mathrm{K}$ deficiency. As mentioned earlier, vitamin $\mathrm{K}$ has anticoagulant properties via activating proteins $\mathrm{C}, \mathrm{S}$, and $\mathrm{Z}$. Contrary to proteins $\mathrm{C}$ and $\mathrm{Z}$, which are mostly synthesized in the liver, half of protein $S$ is produced in endothelial cells and so plays a vital role in the prevention of local thrombosis [190]. Interestingly, vitamin $\mathrm{K} 1$ administration had no influence on VKA anticoagulant efficacy; nevertheless, high doses of vitamin K2 (MK-7, MK-8, MK-9, and larger isoforms) indicated that patients receiving VKA should avoid eating foods or taking supplements containing large amounts of K2 analogs. Furthermore, vitamin $\mathrm{K}$ has the ability to suppress the development of arterial calcification via triggering MGP. In pulmonary disease, low vitamin $\mathrm{K}$ levels have been attributed to greater elastin degradation. Vitamin K-dependent MGP hinders the mineralization of elastic fibers, which are important components of the extracellular matrix (ECM) and play a role in lung fibrosis [191].

Vitamin K is an immunomodulatory agent that inhibits the production of pro-inflammatory cytokines such as IFN-,

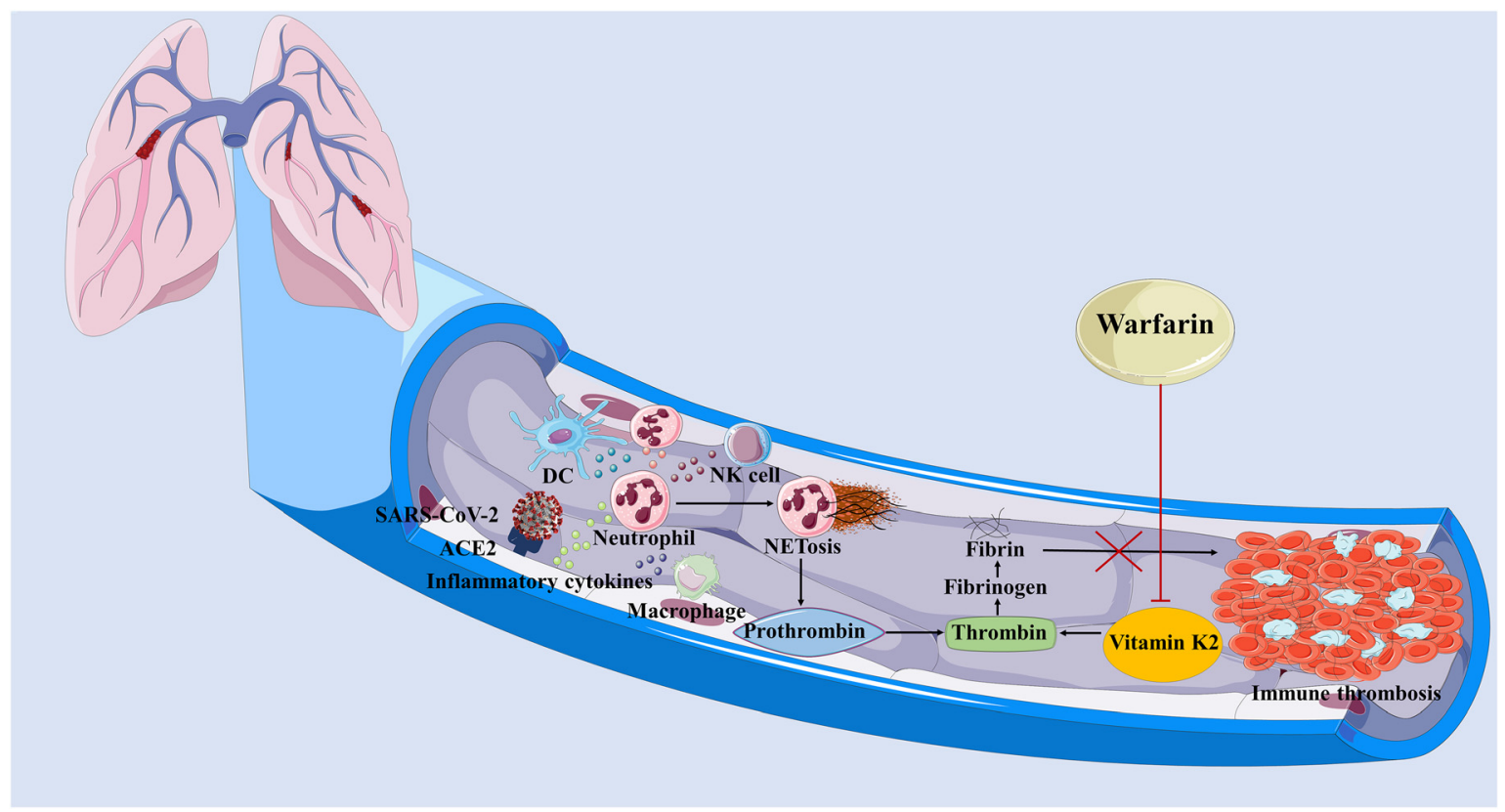

Figure 2: Warfarin-vitamin K2 interaction in the prevention of SARS-CoV-2-induced immune thrombosis.

Blood clotting complications are frequent in COVID-19, and proinflammatory cytokines and NETosis following SARS-CoV-2 infection play an important role in clot formation. Vitamin $\mathrm{K} 2$ contributes to the production of many proteins, most particularly prothrombin, which is a vitamin K2-dependent protein that is directly involved in blood clotting. Warfarin inhibits the function of vitamin K2, which tends to increase the time it takes for a clot to form. This is the intended outcome of the therapy. Increasing the vitamin K2 supplementation while taking warfarin will provoke the drug to operate against the body. ACE2, Angiotensin-converting enzyme 2; DC, Dendritic cell; NK, Natural killer; SARS-CoV-2, Severe acute respiratory syndrome coronavirus 2; NET, Neutrophil extracellular trap. 
IL-6, IL-2, and others, which are among the cytokines that contribute to the severity of COVID-19 and the onset of ARDS [192, 193]. Additionally, further research revealed that vitamin $\mathrm{K} 2$, particularly menaquinone-4, was a more potent anti inflammatory agent than vitamin K1 [194]. Furthermore, vitamin $\mathrm{K}$ can activate proteins $\mathrm{C}$ and $\mathrm{S}$, which downregulate natural anticoagulant pathways and initiate an increase in procoagulant activity, compromising the force balance in the alveolar epithelium and, collectively, play a protective role in maintaining the alveolar membrane's integrity [195-197].

Activated protein C (APC) is an anticoagulant protein that is formed after the activation of protein $\mathrm{C}$ by the thrombin-thrombomodulin complex on the surface of cells, including alveolar epithelial cells. The endothelial protein $\mathrm{C}$ receptor (EPCR) accelerates protein $\mathrm{C}$ activation in a concentration-dependent manner [198]. Thus, vitamin $\mathrm{K}$ supplementation may assist to reduce cytokine levels while also protecting the integrity of the alveolar-capillary membrane, lowering the risk of ARDS development in COVID-19 patients [199].

\section{Conclusion}

The recent COVID-19 pandemic has widely enlightened us that, despite scientific advances, the emergence of a novel infectious disease can put humans in jeopardy, and that introducing an effective approach and immunization can be time-consuming and fraught with high mortality. So, elucidating the precise pathogenesis and determinants factor associated with disease severity is the primary concern of researchers in order to design a definite approach. It is noticeable that novel approaches will have unequal distributions throughout the world, and in pandemics, the main issue of concern is time. As a result, the most challenging research consideration is designating some more accessible approaches applicable to these emerging diseases. In this context, vitamin supplementation is the most accessible and feasible approach that can even be obtained through diet, so study on these micronutrients and their efficacy is critical. Recent clinical studies have revealed that COVID-19 patients have some micronutrients deficiency, which is associated with severe outcomes, recommending vitamin supplementation as an adjunctive treatment option in these patients. However, research has yet to determine optimal dosage and the most effective micronutrient combination in these interventions. It has been established that these micronutrients are immunoregulatory agents that modulate and enhance immune cell functionality, which is an appropriate priority in infectious disease; they also serve some antiviral activities that are synergistic with current antiviral pharmaceutical approaches. These supplements have been shown to attenuate the severity of COVID-19 complications such as RAS dysfunction, coagulopathies, and so on. As a result, suboptimal micronutrient levels in these patients can facilitate SARS-CoV-2 pathogenesis, which suggests that habitual vitamin supplementation, even in vitamin-replete individuals, will lead to improved prophylaxis and prognosis. Furthermore, prior research has shown that these supplements improve the humoral immune response induced by vaccination, underpinning the question of how to integrate these micronutrients with vaccination strategies to terminate pandemics.

Research funding: This research was supported by the Infectious and Tropical Diseases Research Center, Tabriz University of Medical Sciences, Tabriz, Iran.

Competing interests: The authors declare that there are no conflicts of interest.

Disclosure: The authors have nothing to disclose.

\section{References}

1. James PT, Ali Z, Armitage AE, Bonell A, Cerami C, Drakesmith H, et al. Could nutrition modulate COVID-19 susceptibility and severity of disease? A systematic review. medRxiv 2020. https:// doi.org/10.1101/2020.10.19.20214395.

2. Hemmat N, Asadzadeh Z, Ahangar NK, Alemohammad H, Najafzadeh B, Derakhshani A, et al. The roles of signaling pathways in SARS-CoV-2 infection; lessons learned from SARS-CoV and MERS-CoV. Arch Virol 2021;166:675-96.

3. Abulmeaty MMA, Aljuraiban GS, Shaikh SM, ALEid NE, Mazrou LRA, Turjoman AA, et al. The efficacy of antioxidant oral supplements on the progression of COVID-19 in non-critically ill patients: a randomized controlled trial. Antioxidants 2021;10. https://doi. org/10.3390/antiox10050804.

4. Aghbash PS, Eslami N, Shirvaliloo M, Baghi HB. Viral coinfections in COVID-19. J Med Virol 2021. https://doi.org/10.1002/jmv.27102.

5. Michos ED, Cainzos-Achirica M. Supplements for the treatment of mild COVID-19-challenging health beliefs with science from $A$ to $Z$. JAMA Netw Open 2021;4:e210431.

6. Rastogi A, Bhansali A, Khare N, Suri V, Yaddanapudi N, Sachdeva N, et al. Short term, high-dose vitamin D supplementation for COVID-19 disease: a randomised, placebo-controlled, study (SHADE study). Postgrad Med 2020. https://doi.org/10.1136/postgradmedj-2020139065.

7. Name JJ, Souza ACR, Vasconcelos AR, Prado PS, Pereira CPM. Zinc, vitamin D and vitamin C: perspectives for COVID-19 with a focus on physical tissue barrier integrity. Front Nutr 2020;7:606398.

8. Kumar P, Kumar M, Bedi O, Gupta M, Kumar S, Jaiswal G, et al. Role of vitamins and minerals as immunity boosters in COVID-19. Inflammopharmacology 2021;29:1001-16. 
9. Mora JR, Iwata M, von Andrian UH. Vitamin effects on the immune system: vitamins $A$ and $D$ take centre stage. Nat Rev Immunol 2008;8:685-98.

10. Lammi C, Arnoldi A. Food-derived antioxidants and COVID-19. J Food Biochem 2021;45:e13557.

11. Trasino SE. A role for retinoids in the treatment of COVID-19? Clin Exp Pharmacol Physiol 2020;47:1765-7.

12. Huang Z, Liu Y, Qi G, Brand D, Zheng S. Role of vitamin A in the immune system. J Clin Med 2018;7:258.

13. McLaren DS, Kraemer K. Manual on vitamin A deficiency disorders (VADD). Basel: Karger Medical and Scientific Publishers; 2012.

14. Larange A, Cheroutre H. Retinoic acid and retinoic acid receptors as pleiotropic modulators of the immune system. Annu Rev Immunol 2016;34:369-94.

15. Pantazi E, Marks E, Stolarczyk E, Lycke N, Noelle RJ, Elgueta R. Cutting edge: retinoic acid signaling in $B$ cells is essential for oral immunization and microflora composition. J Immunol 2015;195: 1368-71.

16. Aranow C. Vitamin D and the immune system. J Invest Med 2011; 59:881-6.

17. Spilianakis CG, Lee GR, Flavell RA. Twisting the Th1/Th2 immune response via the retinoid $X$ receptor: lessons from a genetic approach. Eur J Immunol 2005;35:3400-4.

18. Murdaca G, Gerosa A, Paladin F, Petrocchi L, Banchero S, Gangemi S. Vitamin D and microbiota: is there a link with allergies? Int J Mol Sci 2021;22. https://doi.org/10.3390/ ijms22084288.

19. Louca P, Murray B, Klaser K, Graham MS, Mazidi M, Leeming ER, et al. Modest effects of dietary supplements during the COVID-19 pandemic: insights from 445850 users of the COVID-19 Symptom Study app. BMJ Nutr Preven Health 2021. https://doi.org/10. 1136/bmjnph-2021-000250.

20. Leal JY, Castejón HV, Romero T, Ortega P, Gómez G, Amaya D, et al. [Serum values of cytokines in children with vitamin $A$ deficiency disorders]. Invest Clin 2004;45:243-56.

21. Michele CA, Angel B, Valeria L, Teresa M, Giuseppe C, Giovanni M, et al. Vitamin supplements in the era of SARS-Cov2 pandemic. GSC Biol Pharmaceut Sci 2020;11:7-019.

22. Sarohan AR. COVID-19: endogenous retinoic acid theory and retinoic acid depletion syndrome. Med Hypotheses 2020;144: 110250.

23. di Bari I, Franzin R, Picerno A, Stasi A, Cimmarusti MT, Di Chiano $M$, et al. Severe acute respiratory syndrome coronavirus 2 may exploit human transcription factors involved in retinoic acid and interferon-mediated response: a hypothesis supported by an in silico analysis. New Microb New Infect 2021;41:100853.

24. Sarohan AR, Akelma H, Arac E, Aslan O. Retinol depletion in severe COVID-19. medRxiv 2021;2021. https://doi.org/10.1101/ 2021.01.30.21250844.

25. Kiser PD, Golczak M, Palczewski K. Chemistry of the retinoid (visual) cycle. Chem Rev 2014;114:194-232.

26. Stephensen $C B$, Lietz $G$. Vitamin $A$ in resistance to and recovery from infection: relevance to SARS-CoV2. Br J Nutr 2021:1-10. https://doi.org/10.1017/s0007114521000246.

27. Berrocal LB, Irriguible TT, Philibert V, Llàcher CT, JBMd O, Domínguez JMM, et al. Zinc and Vitamin a Deficiency Predisposes to the Need for Intubation and Icu Admission in Patients With COVID-19. An Observational Study 2020.
28. Hummel T, Whitcroft KL, Rueter G, Haehner A. Intranasal vitamin A is beneficial in post-infectious olfactory loss. Eur Arch Oto-RhinoLaryngol 2017;274:2819-25.

29. Nguyen NN, Hoang VT, Lagier J-C, Raoult D, Gautret P. Long-term persistence of olfactory and gustatory disorders in COVID-19 patients. Clin Microbiol Infect 2021;27:931-2.

30. Reddy R, Yaghmour B. Severe acute respiratory distress syndrome secondary to all-trans retinoic acid lung toxicity. Chest 2016;150:494A.

31. Yang C, Yang X, Du J, Wang H, Li H, Zeng L, et al. Retinoic acid promotes the endogenous repair of lung stem/progenitor cells in combined with simvastatin after acute lung injury: a stereological analysis. Respir Res 2015;16:140.

32. Al-Sumiadai MM, Ghazzay H, Saleh Al-Dulaimy WZ. Therapeutic effect of Vitamin A on severe COVID-19 patients. Eurasia J Biosci 2020;14:7347-50.

33. Midha IK, Kumar N, Kumar A, Madan T. Mega doses of retinol: a possible immunomodulation in Covid-19 illness in resourcelimited settings. Rev Med Virol 2020;e2204.

34. Singh V. Can vitamins, as epigenetic modifiers, enhance immunity in COVID-19 patients with non-communicable disease? Curr Nutr Rep 2020;9:202-9.

35. Ragan I, Hartson L, Pidcoke H, Bowen R, Goodrich R. Pathogen reduction of SARS-CoV-2 virus in plasma and whole blood using riboflavin and UV light. PloS One 2020;15:e0233947.

36. Shakoor H, Feehan J, Mikkelsen K, Al Dhaheri AS, Ali HI, Platat C, et al. Be well: a potential role for vitamin B in COVID-19. Maturitas 2021;144:108-111.

37. dos Santos LMJ. Can vitamin B12 be an adjuvant to COVID-19 treatment? GSC Biol Pharmaceut Sci 2020;11:001-5.

38. Yoshii K, Hosomi K, Sawane K, Kunisawa J. Metabolism of dietary and microbial vitamin $B$ family in the regulation of host immunity. Front Nutr 2019;6:48.

39. Kunisawa J, Kiyono H. Vitamin-mediated regulation of intestinal immunity. Front Immunol 2013;4:189.

40. Vatsalya V, Li F, Frimodig J, Gala KS, Srivastava S, Kong M, et al. Repurposing treatment of wernicke-korsakoff syndrome for Th-17 cell immune storm syndrome and neurological symptoms in COVID-19: thiamine efficacy and safety, in-vitro evidence and pharmacokinetic profile. Front Pharmacol 2020;11:598128.

41. Branco de Oliveira MV, Irikura S, Lourenço FHdB, Shinsato M, Irikura TCDB, Irikura RB, et al. Encephalopathy responsive to thiamine in severe COVID-19 patients. Brain Behav Immun Health 2021;14:100252.

42. Branco de Oliveira MV, Bernabé DG, Irikura S, Irikura RB, Fontanelli AM, Gonçalves MVM. Wernicke encephalopathy in COVID-19 patients: report of three cases. Front Neurol 2021;12: 629273.

43. Al Sulaiman K, Aljuhani O, Al Dossari M, Alshahrani A, Alharbi A, Algarni $R$, et al. Evaluation of thiamine as adjunctive therapy in COVID-19 critically ill patients: a two-center propensity score matched study. Crit Care 2021;25:223.

44. Keil SD, Ragan I, Yonemura S, Hartson L, Dart NK, Bowen R. Inactivation of severe acute respiratory syndrome coronavirus 2 in plasma and platelet products using a riboflavin and ultraviolet light-based photochemical treatment. Vox Sang 2020;115: 495-501.

45. Mueller AL, McNamara MS, Sinclair DA. Why does COVID-19 disproportionately affect older people? Aging (Albany NY) 2020; 12:9959-81. 
46. Badawy AA. Immunotherapy of COVID-19 with poly (ADP-ribose) polymerase inhibitors: starting with nicotinamide. Biosci Rep 2020;40. https://doi.org/10.1042/BSR20202856.

47. Goli M. Review of novel human $\beta$-coronavirus (2019-nCoV or SARS-CoV-2) from the food industry perspective-Appropriate approaches to food production technology. Food Sci Nutr 2020;8: 5228-37.

48. Brem AS. Electrolyte disorders associated with respiratory distress syndrome and bronchopulmonary dysplasia. Clin Perinatol 1992;19:223-32.

49. Mikkelsen K, Stojanovska L, Apostolopoulos V. The effects of vitamin B in depression. Curr Med Chem 2016;23:4317-37.

50. Nagai A, Matsumiya H, Hayashi M, Yasui S, Okamoto H, Konno K. Effects of nicotinamide and niacin on bleomycin-induced acute injury and subsequent fibrosis in hamster lungs. Exp Lung Res 1994;20:263-81.

51. Rauch BH. Sphingosine 1-phosphate as a link between blood coagulation and inflammation. Cell Physiol Biochem 2014;34: 185-96.

52. Desbarats J. Pyridoxal 5'-phosphate to mitigate immune dysregulation and coagulopathy in COVID-19; 2020.

53. Qian B, Shen S, Zhang J, Jing P. Effects of vitamin B6 deficiency on the composition and functional potential of T cell populations. J Immunol Res 2017;2017:2197975.

54. Lobo V, Patil A, Phatak A, Chandra N. Free radicals, antioxidants and functional foods: impact on human health. Pharmacogn Rev 2010;4:118-26.

55. Liang J, Han Q, Tan Y, Ding H, Li J. Current advances on structurefunction relationships of pyridoxal 5'-phosphate-dependent enzymes. Front Mol Biosci 2019;6:4

56. Tay MZ, Poh CM, Rénia L, MacAry PA, Ng LFP. The trinity of COVID-19: immunity, inflammation and intervention. Nat Rev Immunol 2020;20:363-74.

57. Travica N, Ried K, Hudson I, Sali A, Scholey A, Pipingas A. Gender differences in plasma vitamin $C$ concentrations and cognitive function: a pilot cross-sectional study in healthy adults. Curr Dev Nutr 2020;4:nzaa038.

58. Liu D, Zeng X, Li X, Mehta JL, Wang X. Role of NLRP3 inflammasome in the pathogenesis of cardiovascular diseases. Basic Res Cardiol 2018;113:5.

59. Kumrungsee T, Zhang P, Chartkul M, Yanaka N, Kato N. Potential role of vitamin B6 in ameliorating the severity of COVID-19 and its complications. Front Nutr 2020;7:562051.

60. Sheybani Z, Dokoohaki MH, Negahdaripour M, Dehdashti M, Zolghadr H, Moghadami M, et al. The role of folic acid in the management of respiratory disease caused by COVID-19. 2020.

61. Kunisawa J, Hashimoto E, Ishikawa I, Kiyono H. A pivotal role of vitamin B9 in the maintenance of regulatory $\mathrm{T}$ cells in vitro and in vivo. PloS One 2012;7:e32094.

62. Meisel E, Efros O, Bleier J, Beit Halevi T, Segal G, Rahav G, et al. Folate levels in patients hospitalized with coronavirus disease 2019. Nutrients 2021;13. https://doi.org/10.3390/nu13030812.

63. Khan NA, Saini H, Mawari G, Kumar S, Hira HS, Daga MK. The effect of folic acid supplementation on hyperhomocysteinemia and pulmonary function parameters in chronic obstructive pulmonary disease: a pilot study. J Clin Diagn Res 2016;10: Oc17-oc21.

64. Wiltshire E, Peña AS, MacKenzie K, Shaw G, Couper J. High dose folic acid is a potential treatment for pulmonary hypertension, including when associated with COVID-19 pneumonia. Med Hypotheses 2020;143:110142.

65. Prajapat M, Shekhar N, Sarma P, Avti P, Singh S, Kaur H, et al. Virtual screening and molecular dynamics study of approved drugs as inhibitors of spike protein S1 domain and ACE2 interaction in SARS-CoV-2. J Mol Graph Model 2020;101:107716.

66. Mikkelsen K, Apostolopoulos V. Vitamin B12, folic acid, and the immune system. In: Nutrition and immunity. New York City: Springer; 2019:103-14 pp.

67. Miller JW, Garrod MG, Allen LH, Haan MN, Green R. Metabolic evidence of vitamin B-12 deficiency, including high homocysteine and methylmalonic acid and low holotranscobalamin, is more pronounced in older adults with elevated plasma folate. Am J Clin Nutr 2009;90:1586-92.

68. Shakoor H, Feehan J, Mikkelsen K, Al Dhaheri AS, Ali HI, Platat C, et al. Be well: a potential role for vitamin B in COVID-19. Maturitas 2021;144:108-11.

69. Wolffenbuttel BHR, Wouters HJCM, Heiner-Fokkema MR, van der Klauw MM. The many faces of cobalamin (vitamin B(12)) deficiency. Mayo Clin Proc Innov Qual Outcomes 2019;3: 200-14.

70. Manzanares W, Hardy G. Farmaconutrición de la vitamina B12 para COVID-19. Revista de Nutrición Clínica y Metabolismo 2021; 4:65.

71. Tamura J, Kubota K, Murakami H, Sawamura M, Matsushima T, Tamura T, et al. Immunomodulation by vitamin B12: augmentation of CD8 + T lymphocytes and natural killer (NK) cell activity in vitamin B12-deficient patients by methyl-B12 treatment. Clin Exp Immunol 1999;116:28-32.

72. Manzanares W, Hardy G. Vitamin B12 Pharmaconutrition for COVID-19. Revista de Nutrición Clínica y Metabolismo 2021;4.

73. Tan CW, Ho LP, Kalimuddin S, Cherng BPZ, Teh YE, Thien SY, et al. Cohort study to evaluate the effect of vitamin $D$, magnesium, and vitamin $B(12)$ in combination on progression to severe outcomes in older patients with coronavirus (COVID-19). Nutrition 2020;7980:111017.

74. Lopes M. Can vitamin B12 be an adjuvant to COVID-19 treatment? GSC Biol Pharmaceut Sci 2020;11:1-5.

75. Lopes S, Gadelha DD, Carvalho MD, Fernandes VO, Montenegro Junior RM. Vitamin B12 deficiency: metabolic effects, clinical evaluation, and treatment. Revista de Medicina da UFC 2019;59:40

76. Hoang BX, Shaw GD, Fang W, Han B. A possible application of high dose vitamin $C$ in the prevention and therapy for coronavirus infections. J Glob Antimicrob Resist 2020. https://doi.org/10. 1016/j.jgar.2020.09.025.

77. Mikirova N, Hunninghake R. Effect of high dose vitamin C on Epstein-Barr viral infection. Med Sci Mon 2014;20:725-32.

78. Colunga Biancatelli RML, Berrill M, Marik PE. The antiviral properties of vitamin C. Expert Rev Anti-infect Ther 2020;18: 99-101.

79. Carr AC, Maggini S. Vitamin $C$ and immune function. Nutrients 2017;9. https://doi.org/10.3390/nu9111211.

80. Mohammed BM, Fisher B, Kraskauskas D, Farkas D, Brophy D, Fowler A, et al. Vitamin C: a novel regulator of neutrophil extracellular trap formation. Nutrients 2013;5:3131-51.

81. Schönrich G, Raftery MJ, Samstag Y. Devilishly radical NETwork in COVID-19: oxidative stress, neutrophil extracellular traps (NETs), and T cell suppression. Adv Biol Regul 2020;77:100741. 
82. Huijskens MJ, Walczak M, Koller N, Briedé JJ, Senden-Gijsbers BLMG, Schnijderberg MC, et al. Technical advance: ascorbic acid induces development of double-positive T cells from human hematopoietic stem cells in the absence of stromal cells. J Leukoc Biol 2014;96:1165-75.

83. Tanaka M, Muto N, Gohda E, Yamamoto I. Enhancement by ascorbic acid 2-glucoside or repeated additions of ascorbate of mitogen-induced IgM and IgG productions by human peripheral blood lymphocytes. Jpn J Pharmacol 1994;66:451-6.

84. Carr AC, Spencer E, Dixon L, Chambers ST. Patients with community acquired pneumonia exhibit depleted vitamin $C$ status and elevated oxidative stress. Nutrients 2020;12:1318.

85. Hemilä H, Louhiala P. Vitamin C may affect lung infections. J R Soc Med 2007;100:495-8.

86. Entrenas Castillo M, Entrenas Costa LM, Vaquero Barrios JM, Alcalá Díaz JF, López Miranda J, Bouillon R, et al. Effect of calcifediol treatment and best available therapy versus best available therapy on intensive care unit admission and mortality among patients hospitalized for COVID-19: a pilot randomized clinical study. J Steroid Biochem Mol Biol 2020;203:105751.

87. Boretti A, Banik BK. Intravenous vitamin C for reduction of cytokines storm in acute respiratory distress syndrome. PharmaNutrition 2020;12:100190.

88. Alcala-Diaz JF, Limia-Perez L, Gomez-Huelgas R, Martin-Escalante MD, Cortes-Rodriguez B, Zambrana-Garcia JL, et al. Calcifediol treatment and hospital mortality due to COVID-19: a cohort study. Nutrients 2021;13. https://doi.org/10. 3390/nu13061760.

89. Annweiler C, Hanotte B, Grandin de l'Eprevier C, Sabatier J-M, Lafaie L, Célarier T. Vitamin D and survival in COVID-19 patients: a quasi-experimental study. J Steroid Biochem Mol Biol 2020;204: 105771.

90. Annweiler G, Corvaisier M, Gautier J, Dubée V, Legrand E, Sacco G, et al. Vitamin $D$ supplementation associated to better survival in hospitalized frail elderly COVID-19 patients: the GERIA-COVID quasi-experimental study. Nutrients 2020;12. https://doi.org/10. 3390/nu12113377.

91. Gao D, Xu M, Wang G, Lv J, Ma X, Guo Y, et al. The efficiency and safety of high-dose vitamin $C$ in patients with COVID-19: a retrospective cohort study. Aging (Albany NY) 2021;13:7020-34.

92. Giannini S, Passeri G, Tripepi G, Sella S, Fusaro M, Arcidiacono G, et al. Effectiveness of in-hospital cholecalciferol use on clinical outcomes in comorbid COVID-19 patients: a hypothesisgenerating study. Nutrients 2021;13. https://doi.org/10.3390/ nu13010219.

93. Hakamifard A, Soltani R, Maghsoudi A, Rismanbaf A, Aalinezhad M, Tarrahi MJ, et al. The effect of vitamin E and vitamin $C$ in patients with COVID-19 pneumonia; a randomized controlled clinical trial. 2021.

94. Hiedra R, Lo KB, Elbashabsheh M, Gul F, Wright RM, Albano J, et al. The use of IV vitamin C for patients with COVID-19: a case series. Expert Rev Anti Infect Ther 2020;18:1259-61.

95. Lakkireddy M, Gadiga SG, Malathi RD, Karra ML, Raju IP, Chinapaka S, et al. Impact of daily high dose oral vitamin D therapy on the inflammatory markers in patients with COVID 19 disease. Sci Rep 2021;11:10641.

96. Murai IH, Fernandes AL, Sales LP, Pinto AJ, Goessler KF, Duran CSC, et al. Effect of a single high dose of vitamin D3 on hospital length of stay in patients with moderate to severe COVID-19: a randomized clinical trial. Jama 2021;325:1053-60.
97. Sabico S, Enani MA, Sheshah E, Aljohani NJ, Aldisi DA, Alotaibi NH, et al. Effects of a 2-week 5000 IU versus 1000 IU vitamin D3 supplementation on recovery of symptoms in patients with mild to moderate covid-19: a randomized clinical trial. Nutrients 2021;13. https://doi.org/10.3390/nu13072170.

98. JamaliMoghadamSiahkali S, Zarezade B, Koolaji S, SeyedAlinaghi S, Zendehdel A, Tabarestani M, et al. Safety and effectiveness of high-dose vitamin C in patients with COVID-19: a randomized open-label clinical trial. Eur J Med Res 2021;26:20.

99. Thomas S, Patel D, Bittel B, Wolski K, Wang Q, Kumar A, et al. Effect of high-dose zinc and ascorbic acid supplementation vs usual care on symptom length and reduction among ambulatory patients with SARS-CoV-2 infection: the COVID A to Z randomized clinical trial. JAMA Netw Open 2021;4:e210369.

100. Zhang J, Rao X, Li Y, Zhu Y, Liu F, Guo G, et al. Pilot trial of highdose vitamin C in critically ill COVID-19 patients. Ann Intensive Care 2021;11:5.

101. Zhao B, Liu M, Liu P, Peng Y, Huang J, Li M, et al. High dose intravenous vitamin $C$ for preventing the disease aggravation of moderate COVID-19 pneumonia. A retrospective propensity matched before-after study. Front Pharmacol 2021;12:638556.

102. Feyaerts AF, Luyten W. Vitamin C as prophylaxis and adjunctive medical treatment for COVID-19? Nutrition 2020; 79-80:110948.

103. Farjana M, Moni A, Sohag AAM, Hasan A, Hannan MA, Hossain $M G$, et al. Repositioning vitamin $C$ as a promising option to alleviate complications associated with COVID-19. Infect Chemother 2020;52:461-77.

104. Burns JJ. Missing step in man, monkey and guinea pig required for the biosynthesis of L-ascorbic acid. Nature 1957;180:553.

105. Johnston CS, Martin LJ, Cai X. Antihistamine effect of supplemental ascorbic acid and neutrophil chemotaxis. J Am Coll Nutr 1992;11:172-6.

106. Carr AC, Cook J. Intravenous vitamin C for cancer therapy identifying the current gaps in our knowledge. Front Physiol 2018;9:1182.

107. Lunec J, Blake DR. The determination of dehydroascorbic acid and ascorbic acid in the serum and synovial fluid of patients with rheumatoid arthritis (RA). Free Radic Res Commun 1985;1: 31-9.

108. Holford P, Carr AC, Jovic TH, Ali SR, Whitaker IS, Marik PE, et al. Vitamin C-an adjunctive therapy for respiratory infection, sepsis and COVID-19. Nutrients 2020;12. https://doi.org/10.3390/ nu12123760.

109. Arcanjo A, Logullo J, Menezes CCB, de Souza Carvalho Giangiarulo TC, dos Reis MC, de Castro GMM, et al. The emerging role of neutrophil extracellular traps in severe acute respiratory syndrome coronavirus 2 (COVID-19). Sci Rep 2020;10:19630.

110. Arvinte C, Singh M, Marik PE. Serum levels of vitamin C and vitamin $D$ in a cohort of critically ill COVID-19 patients of a north American community hospital intensive care unit in may 2020: a pilot study. Med Drug Discov 2020;8:100064.

111. Waqas Khan HM, Parikh N, Megala SM, Predeteanu GS. Unusual early recovery of a critical COVID-19 patient After administration of intravenous vitamin C. Am J Case Rep 2020;21:e925521.

112. Liu B, Li M, Zhou Z, Guan X, Xiang Y. Can we use interleukin-6 (IL-6) blockade for coronavirus disease 2019 (COVID-19)induced cytokine release syndrome (CRS)? J Autoimmun 2020; 111:102452. 
113. Hemilä $\mathrm{H}$, Chalker E. Vitamin $\mathrm{C}$ may reduce the duration of mechanical ventilation in critically ill patients: a metaregression analysis. J Intensive Care 2020;8:15.

114. Carr AC. Micronutrient status of COVID-19 patients: a critical consideration. Crit Care 2020;24:1-2.

115. Weir EK, Thenappan T, Bhargava M, Chen Y. Does vitamin D deficiency increase the severity of COVID-19? Clin Med 2020;20: e107.

116. Siddiqui M, Manansala JS, Abdulrahman HA, Nasrallah GK, Smatti MK, Younes N, et al. Immune modulatory effects of vitamin D on viral infections. Nutrients 2020;12. https://doi. org/10.3390/nu12092879.

117. Luo X, Liao Q, Shen Y, Li H, Cheng L. Vitamin D deficiency is associated with COVID-19 incidence and disease severity in Chinese people [corrected]. J Nutr 2021;151:98-103.

118. Radujkovic A, Hippchen T, Tiwari-Heckler S, Dreher S, Boxberger M, Merle U. Vitamin D deficiency and outcome of COVID-19 patients. Nutrients 2020;12. https://doi.org/10. 3390/nu12092757.

119. Meltzer DO, Best TJ, Zhang H, Vokes T, Arora V, Solway J. Association of vitamin D status and other clinical characteristics with COVID-19 test results. JAMA Netw Open 2020;3:e2019722.

120. Ali N. Role of vitamin D in preventing of COVID-19 infection, progression and severity. J Infect Public Health 2020;13:1373-80.

121. Padhi S, Suvankar S, Panda VK, Pati A, Panda AK. Lower levels of vitamin $D$ are associated with SARS-CoV-2 infection and mortality in the Indian population: an observational study. Int Immunopharm 2020;88:107001.

122. Mateo M, Generous A, Sinn PL, Cattaneo R. Connections matterhow viruses use cell-cell adhesion components. J Cell Sci 2015; 128:431-9.

123. Brandenburg VM, Vervloet MG, Marx N. The role of vitamin D in cardiovascular disease: from present evidence to future perspectives. Atherosclerosis 2012;225:253-63.

124. Kim D-H, Meza CA, Clarke H, Kim J-S, Hickner RC. Vitamin D and endothelial function. Nutrients 2020;12:575.

125. Brodowski L, Schröder-Heurich B, Hubel CA, Vu TH, von Kaisenberg CS, von Versen-Höynck F. Role of vitamin D in cell-cell interaction of fetal endothelial progenitor cells and umbilical cord endothelial cells in a preeclampsia-like model. Am J Physiol Cell Physiol 2019;317:C348-c357.

126. Ni W, Yang X, Yang D, Bao J, Li R, Xiao Y, et al. Role of angiotensin-converting enzyme 2 (ACE2) in COVID-19. Crit Care 2020;24:422.

127. Santoro D, Caccamo D, Lucisano S, Buemi M, Sebekova K, Teta D, et al. Interplay of vitamin D, erythropoiesis, and the renin-angiotensin system. BioMed Res Int 2015;2015:145828.

128. Wang R, DeGruttola V, Lei Q, Mayer KH, Redline S, Hazra A, et al. The vitamin D for COVID-19 (VIVID) trial: a pragmatic cluster-randomized design. Contemp Clin Trials 2021;100: 106176.

129. Mendoza A, Lazartigues $E$. The compensatory renin-angiotensin system in the central regulation of arterial pressure: new avenues and new challenges. Ther Adv Cardiovasc Dis 2015;9:201-8.

130. Sarkesh A, Daei Sorkhabi A, Sheykhsaran E, Alinezhad F, Mohammadzadeh N, Hemmat N, et al. Extrapulmonary clinical manifestations in COVID-19 patients. Am J Trop Med Hyg 2020; 103:1783-96.
131. Aygun H. Vitamin D can prevent COVID-19 infection-induced multiple organ damage. Naunyn-Schmiedeberg's Arch Pharmacol 2020;393:1157-60.

132. Verdecchia P, Cavallini C, Spanevello A, Angeli F. The pivotal link between ACE2 deficiency and SARS-CoV-2 infection. Eur J Intern Med 2020;76:14-20.

133. Yuan W, Pan W, Kong J, Zheng W, Szeto FL, Wong KE, et al. 1,25-dihydroxyvitamin D3 suppresses renin gene transcription by blocking the activity of the cyclic AMP response element in the renin gene promoter. J Biol Chem 2007;282:29821-30.

134. Gracia-Ramos AE. Is the ACE2 overexpression a risk factor for COVID-19 infection? Arch Med Res 2020;51:345-6.

135. Shi Y, Wang Y, Shao C, Huang J, Gan J, Huang X, et al. COVID-19 infection: the perspectives on immune responses. Cell Death Differ 2020;27:1451-4.

136. Luo P, Liu Y, Qiu L, Liu X, Liu D, Li J. Tocilizumab treatment in COVID-19: a single center experience. J Med Virol 2020;92: 814-8.

137. Di Rosa M, Malaguarnera M, Nicoletti F, Malaguarnera L. Vitamin D3: a helpful immuno-modulator. Immunology 2011;134: 123-39.

138. Rigby WF, Stacy T, Fanger MW. Inhibition of T lymphocyte mitogenesis by 1,25-dihydroxyvitamin D3 (calcitriol). J Clin Invest 1984;74:1451-5.

139. Adams JS, Hewison M. Unexpected actions of vitamin D: new perspectives on the regulation of innate and adaptive immunity. Nat Clin Pract Endocrinol Metabol 2008;4:80-90.

140. Gunville CF, Mourani PM, Ginde AA. The role of vitamin D in prevention and treatment of infection. Inflamm Allergy - Drug Targets 2013;12:239-45.

141. Aghbash PS, Eslami N, Shamekh A, Entezari-Maleki T, Baghi HB. SARS-CoV-2 infection: the role of PD-1/PD-L1 and CTLA-4 axis. Life Sci 2021;270:119124.

142. Kim SJ. SLE-associated risk factors affect DC function. Curr Rheumatol Rep 2019;21:4.

143. Boulkrane MS, Ilina V, Melchakov R, Fedotova J, Drago F, Gozzo L, et al. COVID-19 disease and vitamin D: a mini-review. Front Pharmacol 2020;11:604579.

144. de Las Heras N, Martín Giménez VM, Ferder L, Manucha W, Lahera V. Implications of oxidative stress and potential role of mitochondrial dysfunction in COVID-19: therapeutic effects of vitamin D. Antioxidants 2020;9. https://doi.org/10.3390/ antiox9090897.

145. Xu Y, Baylink DJ, Chen C-S, Reeves ME, Xiao J, Lacy C, et al. The importance of vitamin d metabolism as a potential prophylactic, immunoregulatory and neuroprotective treatment for COVID-19. J Transl Med 2020;18:322.

146. Zhang J, Tecson KM, McCullough PA. Endothelial dysfunction contributes to COVID-19-associated vascular inflammation and coagulopathy. Rev Cardiovasc Med 2020;21:315-9.

147. Liu PT, Stenger S, Li H, Wenzel L, Tan BH, Krutzik SR, et al. Tolllike receptor triggering of a vitamin D-mediated human antimicrobial response. Science 2006;311:1770-3.

148. Teymoori-Rad M, Marashi SM. Vitamin D and Covid-19: from potential therapeutic effects to unanswered questions. Rev Med Virol 2020:e2159. https://doi.org/10.1002/rmv. 2159. 
149. Market M, Angka L, Martel AB, Bastin D, Olanubi O, Tennakoon $\mathrm{G}$, et al. Flattening the COVID-19 curve with natural killer cell based immunotherapies. Front Immunol 2020;11:1512.

150. Wrzosek M, tukaszkiewicz J, Wrzosek M, Jakubczyk A, Matsumoto H, Piątkiewicz P, et al. Vitamin D and the central nervous system. Pharmacol Rep 2013;65:271-8.

151. Montalvan V, Lee J, Bueso T, De Toledo J, Rivas K. Neurological manifestations of COVID-19 and other coronavirus infections: a systematic review. Clin Neurol Neurosurg 2020;194:105921.

152. Di Somma C, Scarano E, Barrea L, Zhukouskaya VV, Savastano S, Mele C, et al. Vitamin D and neurological diseases: an endocrine view. Int J Mol Sci 2017;18. https://doi.org/10.3390/ ijms18112482.

153. Im JH, Je YS, Baek J, Chung M-H, Kwon HY, Lee J-S. Nutritional status of patients with COVID-19. Int J Infect Dis 2020;100:390-3.

154. Wortsman J, Matsuoka LY, Chen TC, Lu Z, Holick MF. Decreased bioavailability of vitamin D in obesity. Am J Clin Nutr 2000;72: 690-3.

155. Gilbert CR, Arum SM, Smith CM. Vitamin D deficiency and chronic lung disease. Canc Res J 2009;16:75-80.

156. Karahan S, Katkat F. Impact of serum $25(\mathrm{OH})$ vitamin D level on mortality in patients with COVID-19 in Turkey. J Nutr Health Aging 2021;25:189-196.

157. Maghbooli Z, Sahraian MA, Ebrahimi M, Pazoki M, Kafan S, Tabriz HM, et al. Vitamin D sufficiency, a serum 25 -hydroxyvitamin $D$ at least $30 \mathrm{ng} / \mathrm{mL}$ reduced risk for adverse clinical outcomes in patients with COVID-19 infection. PloS One 2020;15:e0239799.

158. Laird, E and R Kenny, Vitamin D deficiency in Ireland implications for COVID 19. Results from the Irish Longitudinal Study on Ageing (TILDA). 2020.

159. Li Y, Cao Z, Guo J, Li Q, Su J. Effects of serum vitamin D levels and vitamin $D$ supplementation on urticaria: a systematic review and meta-analysis. Int J Environ Res Publ Health 2021;18. https:// doi.org/10.3390/ijerph18094911.

160. Martineau AR, Jolliffe DA, Hooper RL, Greenberg L, Aloia JF, Bergman $P$, et al. Vitamin D supplementation to prevent acute respiratory tract infections: systematic review and metaanalysis of individual participant data. bmj 2017;356:16583.

161. Einarsdóttir K, Preen DB, Clay TD, Kiely L, Holman CDAJ, Cohen LD. Effect of a single 'megadose' intramuscular vitamin $D$ $(600,000 \mathrm{IU})$ injection on vitamin $\mathrm{D}$ concentrations and bone mineral density following biliopancreatic diversion surgery. Obes Surg 2010;20:732-7.

162. Liu G, Hong T, Yang J. A single large dose of vitamin D could be used as a means of coronavirus disease 2019 prevention and treatment. Drug Des Dev Ther 2020;14:3429.

163. Walk J, Dofferhoff ASM, van den Ouweland JMW, van Daal H, Janssen R. Vitamin D-contrary to vitamin K-does not associate with clinical outcome in hospitalized COVID-19 patients. medRxiv 2020. https://doi.org/10.1101/2020.11.07.20227512.

164. Hejazi ME, Modarresi-Ghazani F, Hamishehkar H, MesgariAbbasi M, Dousti S, Entezari-Maleki T. The effect of treatment of vitamin D deficiency on the level of P-selectin and hs-CRP in patients with thromboembolism: a pilot randomized clinical trial. J Clin Pharmacol 2017;57:40-7.

165. Rhodes JM, Subramanian S, Laird E, Griffin G, Kenny RA, et al. Perspective: vitamin D deficiency and COVID-19 severity plausibly linked by latitude, ethnicity, impacts on cytokines, ACE2 and thrombosis. J Intern Med 2021;289:97-115.
166. Lemke G, Silverman GJ. Blood clots and TAM receptor signalling in COVID-19 pathogenesis. Nat Rev Immunol 2020; 20:395-6.

167. Stoichitoiu LE, Pinte L, Balea MI, Nedelcu V, Badea C, Baicus C. Anticoagulant protein S in COVID-19: low activity, and associated with outcome. Rom J Intern Med 2020;58:251-8.

168. Uwitonze $A M$, Razzaque MS. Role of magnesium in vitamin $D$ activation and function. J Am Osteopath Assoc 2018;118:181-9.

169. Caspi R, Altman T, Billington R, Dreher K, Foerster H, Fulcher CA, et al. The MetaCyc database of metabolic pathways and enzymes and the BioCyc collection of Pathway/Genome Databases. Nucleic Acids Res 2014;42:D459-71.

170. Lee GY, Han SN. The role of vitamin E in immunity. Nutrients 2018;10. https://doi.org/10.3390/nu10111614.

171. Hinman A, Holst CR, Latham JC, Bruegger JJ, Ulas G, McCusker $\mathrm{KP}$, et al. Vitamin $\mathrm{E}$ hydroquinone is an endogenous regulator of ferroptosis via redox control of 15-lipoxygenase. PloS One 2018; 13:e0201369.

172. Carlson BA, Tobe R, Yefremova E, Tsuji PA, Hoffmann VJ, Schweizer U, et al. Glutathione peroxidase 4 and vitamin $\mathrm{E}$ cooperatively prevent hepatocellular degeneration. Redox Biol 2016;9:22-31.

173. Tavakol S, Seifalian AM. Vitamin E at a high dose as an antiferroptosis drug and not just a supplement for COVID-19 treatment. Biotechnol Appl Biochem 2021. https://doi.org/10. 1002/bab.2176.

174. Richard C, Lemonnier F, Thibault M, Couturier M, Auzepy P. Vitamin E deficiency and lipoperoxidation during adult respiratory distress syndrome. Crit Care Med 1990;18:4-9.

175. Calder PC, Carr AC, Gombart AF, Eggersdorfer M. Optimal nutritional status for a well-functioning immune system is an important factor to protect against viral infections. Nutrients 2020;12. https://doi.org/10.3390/nu12082326.

176. Jovic TH, Ali SR, Ibrahim N, Jessop ZM, Tarassoli SP, Dobbs TD, et al. Could vitamins help in the fight against COVID-19? Nutrients 2020;12. https://doi.org/10.3390/nu12092550.

177. Marko MG, Ahmed T, Bunnell SC, Wu D, Chung H, Huber BT, et al. Age-associated decline in effective immune synapse formation of CD4(+) T cells is reversed by vitamin E supplementation. J Immunol 2007;178:1443-9.

178. Meydani SN, et al. Vitamin E supplementation and in vivo immune response in healthy elderly subjects. A randomized controlled trial. Jama 1997;277:1380-6.

179. Adolfsson O, Huber BT, Meydani SN. Vitamin E-enhanced IL-2 production in old mice: naive but not memory $\mathrm{T}$ cells show increased cell division cycling and IL-2-producing capacity. J Immunol 2001;167:3809-17.

180. Kudelko M, Yip TF, Hei Law GC, Lee SMY. Potential beneficial effects of vitamin $\mathrm{K}$ in SARS-CoV-2 induced vascular disease? Immuno 2021;1:17-29.

181. Dofferhoff ASM, Piscaer I, Schurgers LJ, Visser MPJ, van den Ouweland JMW, de Jong PA, et al. Reduced vitamin K status as a potentially modifiable risk factor of severe COVID-19. Clin Infect Dis 2020. https://doi.org/10.1093/cid/ciaa1258.

182. Janssen R, Visser MPJ, Dofferhoff ASM, Vermeer C, Janssens W, Walk J. Vitamin $\mathrm{K}$ metabolism as the potential missing link between lung damage and thromboembolism in Coronavirus disease 2019. Br J Nutr 2021;126:191-8.

183. Dofferhoff, ASM, Piscaer I, Schurgers LJ, Visser MPJ, van den Ouweland JMW, de Jong PA, et al. Reduced vitamin K 
status as a potentially modifiable prognostic risk factor in COVID-19; 2020. Available from: https://www.preprints.org.

184. Roumeliotis S, Roumeliotis A, Stamou A, Leivaditis K, Kantartzi K, Panagoutsos S, et al. The association of dp-ucMGP with cardiovascular morbidity and decreased renal function in diabetic chronic kidney disease. Int J Mol Sci 2020;21. https://doi.org/10. 3390/ijms21176035.

185. Anastasi E, lalongo C, Labriola R, Ferraguti G, Lucarelli M, Angeloni A. Vitamin K deficiency and covid-19. Scand J Clin Lab Invest 2020;80:525-7.

186. Shea MK, O’Donnell CJ, Hoffmann U, Dallal GE, Dawson-Hughes $B$, Ordovas JM, et al. Vitamin K supplementation and progression of coronary artery calcium in older men and women. Am J Clin Nutr 2009;89:1799-807.

187. Goddek S. Vitamin D3 and K2 and their potential contribution to reducing the COVID-19 mortality rate. Int J Infect Dis 2020;99: 286-90.

188. Schurgers LJ, Shearer MJ, Hamulyák K, Stöcklin E, Vermeer C. Effect of vitamin $\mathrm{K}$ intake on the stability of oral anticoagulant treatment: dose-response relationships in healthy subjects. Blood 2004;104:2682-9.

189. STAFFORD DW. The vitamin K cycle. J Thromb Haemostasis 2005; 3:1873-8.

190. Tie JK, Stafford DW. Structure and function of vitamin K epoxide reductase. Vitam Horm 2008;78:103-30.

191. De Brouwer B, Piscaer I, Von Der Thusen JH, Grutters JC, Schutgens RE, Wouters EF, et al. Should vitamin K be supplemented instead of antagonised in patients with idiopathic pulmonary fibrosis? Expet Rev Respir Med 2018;12: 169-75.
192. Conti P, Ronconi G, Caraffa A, Gallenga CE, Ross R, Frydas I, et al. Induction of pro-inflammatory cytokines (IL-1 and IL-6) and lung inflammation by Coronavirus-19 (COVI-19 or SARS-CoV-2): antiinflammatory strategies. J Biol Regul Homeost Agents 2020;34: 327-31.

193. Donyavi T, Bokharaei-Salim F, Baghi HB, Khanaliha K, Alaei JanatMakan M, Karimi B, et al. Acute and post-acute phase of COVID-19: analyzing expression patterns of miRNA-29a-3p, 146a-3p, 155-5p, and let-7b-3p in PBMC. Int Immunopharm 2021;97:107641.

194. Hodges SJ, Pitsillides AA, Ytrebø LM, Soper R. Anti-inflammatory actions of vitamin K. Vitam K2: Vital Health Wellbeing 2017;153. https://doi.org/10.5772/63891.

195. Popa DS, Bigman G, Rusu ME. The role of vitamin K in humans: implication in aging and age-associated diseases. Antioxidants 2021;10. https://doi.org/10.3390/antiox10040566.

196. Berkner KL, Runge KW. The physiology of vitamin K nutriture and vitamin K-dependent protein function in atherosclerosis. J Thromb Haemostasis 2004;2:2118-32.

197. Puig F, Fuster G, Adda M, Blanch L, Farre R, Navajas D, et al. Barrier-protective effects of activated protein $C$ in human alveolar epithelial cells. PloS One 2013;8:e56965.

198. Sehlmeyer K, Ruwisch J, Roldan N, Lopez-Rodriguez E. Alveolar dynamics and beyond - the importance of surfactant protein $C$ and cholesterol in lung homeostasis and fibrosis. Front Physiol 2020;11:386.

199. Tutusaus A, Marí M, Ortiz-Pérez JT, Nicolaes GAF, Morales A, García de Frutos P. Role of vitamin K-dependent factors protein $S$ and GAS6 and TAM receptors in SARS-CoV-2 infection and COVID-19-associated immunothrombosis. Cells 2020;9. https://doi.org/10.3390/cells9102186. 